\title{
The Actinomycete-genus Rhodococcus: A Home for the 'rhodochrous' Complex
}

\author{
By M. GOODFELLOW AND GRACE ALDERSON \\ Department of Microbiology, The Medical School, \\ The University, Newcastle upon Tyne $N E_{\mathrm{I}}{ }_{7} R U$
}

(Received 28 September 1976)

\begin{abstract}
SUMMAR Y
A numerical taxonomic classification study was carried out on 177 strains representing the 'rhodochrous' complex and the genera Gordona, Mycobacterium and Nocardia. The strains were examined for 92 unit characters and the data were analysed by computer. Three clusters were defined at the 75 to $80 \%$ similarity level. The first was a heterogeneous cluster corresponding to the 'rhodochrous' taxon whereas the other two contained Mycobacterium and Nocardia strains respectively. The good correlation between the numerical analysis and chemotaxonomic, serological and genetical data collected from previous studies provides sufficient evidence for raising the 'rhodochrous' taxon to generic status. We consider the generic name Rhodococcus Zopf to have priority over Proactinomyces (Jensen) Bradley \& Bond, Jensenia Bisset \& Moore and Gordona Tsukamura. In addition to the type species, Rhodococcus rhodochrous, nine species are recognized: $R$. bronchialis, $R$. coprophilus, $R$. corallinus, $R$. erythropolis, $R$. equi, $R$. rhodnii, $R$. rubrus, $R$. rubropertinctus and $R$. terrae.
\end{abstract}

\section{INTRODUCTION}

The taxonomic history of bacteria classified variously as Mycobacterium rhodochrous (Overbeck, I 89I; Gordon \& Mihm, I957), the 'rhodochrous' complex (Bradley, 197I), the 'rhodochrous' taxon (Goodfellow et al., 1974) or the $M$. rhodochrous complex (Cross \& Rowbotham, 1974) has been traced by Bousfield \& Goodfellow (1976). Gordon \& Mihm (1957) proposed the taxon Mycobacterium rhodochrous for a group of similar strains which they had received under a plethora of generic and specific names, the oldest being Rhodococcus rhodochrous Overbeck 189I ; Zopf 189I. In subsequent studies (Gordon \& Mihm, 1959, I96I; Gordon, I966) further nomenclatural species were reduced to synonyms of $M$. rhodochrous and a more comprehensive description of the taxon was given. Gordon (I966) noted some variation in rhodochrous strains but nevertheless described them as a good species in search of a genus; Nocardia, Mycobacterium and Corynebacterium were offered as possible niches. However, in the eighth edition of Bergey's Manual of Determinative Bacteriology, bacteria formerly assigned to $M$. rhodochrous are scattered amongst species of Nocardia with the proviso that further work was needed to clarify their taxonomic position (McClung, 1974; Runyon, Wayne \& Kubica, 1974).

The 'rhodochrous' complex forms a recognizable but heterogeneous taxon and can be distinguished from Mycobacterium and Nocardia on the basis of antibiotic sensitivity (Goodfellow \& Orchard, I974), chemical (Ratledge \& Patel, 1976a, b), DNA reassociation (Bradley \& Mordarski, 1976; Mordarski et al., I976, 1977), numerical phenetic (Goodfellow et al., 1974; Bousfield \& Goodfellow, 1976), serological (Ridell \& Norlin, 1973; 
Lind \& Ridell, 1976) and phage-susceptibility studies (Manion et al., 1964; Jones \& Bradley, 1964; Pietkiewicz et al., 1974). There is, however, little agreement on the internal structure of the taxon and comparisons between different studies are hampered by the paucity of extant type cultures and the questionable identification of many strains.

The heterogeneity of the 'rhodochrous' complex is most clearly seen from numerical phenetic studies (Bradley, 197I ; Goodfellow, 197I ; Tacquet et al., I97I ; Goodfellow et al., I974; Jones, 1975) but is also apparent from chemical (Goodfellow et al., I974; Collins et al., I977; Alshamaony et al., I976a,b), DNA:DNA pairing (Clark, Brownell \& Bradley, I97I ; Bradley, I973; Bradley \& Mordarski, I976; Mordarski et al., 1976, I977), physiological (Gordon, 1966; Lechevalier \& Lechevalier, 1974; Mordarska, Mordarski \& Pietkiewicz, 1973), serological (Magnusson, 1962; Ridell, 1974; Lind \& Ridell, 1976), genetical and actinophage studies (Brownell, Adams \& Bradley, I967; Adams, Adams \& Brownell, 1970). Since few strains are common to all of these investigations it is difficult to determine whether or not, and to what extent, defined groups overlap. The taxonomic situation is further confused by the placing of some strains, similar to rhodochrous bacteria, in the genus Gordona (Tsukamura, 197I). This genus is listed as incertae sedis in the current edition of Bergey's Mantial of Determinative Bacteriology (McClung, 1974).

As originally proposed, the genus Gordona contained the species Gordona bronchialis, G. rubra and G. terrae (Tsukamura, 197I). A further species, G. alirantiaca, was described by Tsukamura \& Mizuno (1971). Subsequently, Tsukamura (1973, 1974, 1975) suggested that some rhodochrous strains should also be classified in the genus and proposed three new species: G. rhodochroa, G. rosea and G. rubropertincta (syn. G. rubra). Strains provisionally classified as Nocardia rubra were also included in the genus as G. lentifragmenta (Tsukamura, Mizuno \& Murata, 1975). The enlarged genus Gordona was distinguished from Nocardia and most Mycobacterium taxa in a comprehensive numerical phenetic analysis (Tsukamura et al., 1975).

Bousfield \& Goodfellow (1976) discussed the taxonomic status of strains of the 'rhodochrous' complex and suggested that they might be classified as Mycobacterium rhodochrous, or reclassified in an alternative established genus or considered as a genus in their own right. Possible generic names, cautiously intimated by Cross \& Goodfellow (1973), were Rhodococcus Zopf I891, Proactinomyces (Jensen 1931) Bradley \& Bond 1974, Jensenia Bisset \& Moore 1950 and Gordona Tsukamura 1971. Of these, Rhodococcus has priority. Although this genus was founded to accommodate pink-pigmented cocci, the only authentic extant strain of the type species, Rhodococcus rhodochronis, is undoubtedly a member of the 'rhodochrous' taxon (see Gordon \& Mihm, 1957).

In the present study, carefully chosen gordonae and rhodochrous strains and marker cultures of Nocardia and Mycobacterium were compared using numerical taxonomic methods in an attempt to clarify the taxonomy of the 'rhodochrous' complex.

\section{METHODS}

Strains. One hundred and forty-two rhodochrous strains, Io gordonae and 25 'marker' cultures of mycobacteria and nocardiae were examined (Table I). The 'markers' were Io strains of rapidly growing mycobacteria belonging to Runyon's group IV (Kubica et al., 1972) and strains of Nocardia asteroides, $N$. brasiliensis and $N$. caviae. All of the cultures were maintained on yeast extract agar (YEA) at room temperature (Goodfellow, I97I).

Collection of data. Data for the N-coded rhodochrous strains were taken from earlier studies (Goodfellow, I97I; Goodfellow, Fleming \& Sackin, 1972). The remaining strains were examined for purity and screened for 92 unit characters (Table 5). 
Table I. Designation and source of cultures assigned to clusters I, 2 and 3

(a) Cultures assigned to subcluster IA

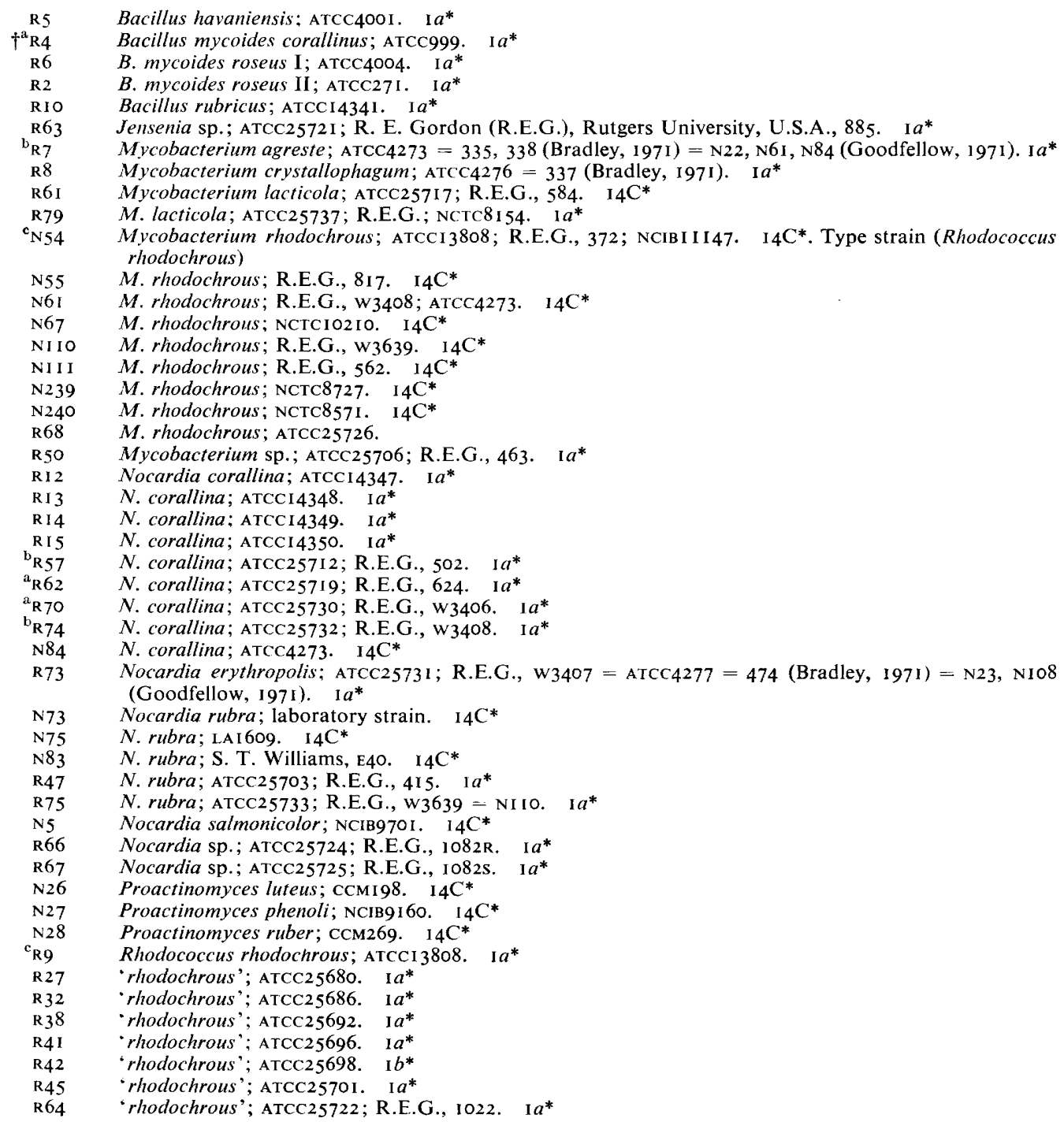

(b) Cultures assigned to subcluster $\mathbf{I B}$

N30 Mycobacterium rhodochrous; R.E.G., Al2974; ATCC12974. I4B*

N3I M. rhodochrous; R.E.G., W2I. Micrococcus rhodochrous Overbeck. I4B*

(c) Cultures assigned to subcluster IC

Gordona bronchialis; NCTC10667; M. Tsukamura, Chuba Chest Hospital, Obu, Aichi-ken 474, Japan, 3410. ATCC25592. Type strain

${ }^{\mathrm{d}} 660 \quad G$. bronchialis; NCTC10667. Type strain

${ }_{\mathrm{N} 655}$ Gordona rubra; NCTC10668; M. Tsukamura, 3605. Type strain

${ }_{\mathrm{e} 657}$ G. rubra; NCrC10668; ATCC25593. Type strain

N658 G. rubra; M. Tsukamura; ATCC60004

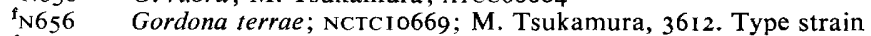

${ }^{\mathrm{f}} 659$ G. terrae; NCTC I0669; ATCC25594. Type strain

N662 G. terrae; H. Mordarska, Hirszfeld Institute, Wrocław, Poland, T6. Type strain

N450 Nocardia corallina; R. Bönicke, Institut für Experimentelle Biologie und Medizin, Borstel, West Germany, SN5303

N45I N. corallina; R. Bönicke, SN5302 


\section{Table I (cont.)}

(d) Cultures assigned to subcluster ID

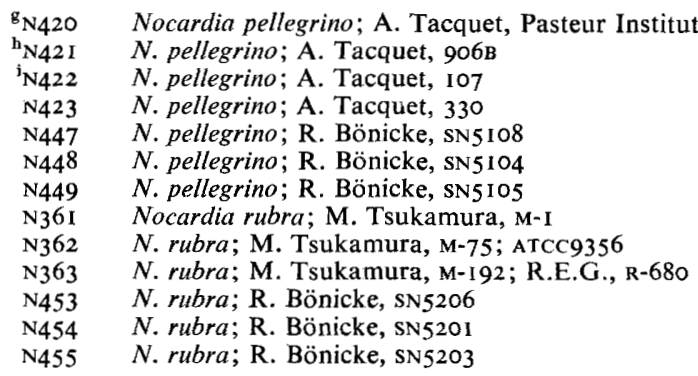

(e) Cultures assigned to subcluster $\mathrm{I} \mathbf{E}$

$\mathrm{N} 324$

${ }^{\mathrm{h}} \mathrm{N} 325$

${ }^{\mathrm{i}} \mathrm{N} 326$

$\mathrm{g}_{\mathrm{N} 327}$

N328

R39

R7 I

R76

R59

R70

R60

Ni46

R69

R49

N59

N66

R65

R46

R78

R5 8

$\mathrm{N} 4$

NII 3

R56

\section{R 17}

RI8
RI9

\section{R2O}

$$
\text { R2 I }
$$

R22

R23

R24

R25

R26

R 28

R29

R30

R 3 I

R33

R34

R35

R43

R5 I

Nocardia pellegrino; ATCCI $5998.14 \mathrm{~A}^{*}$

N. pellegrino; G. Castelnuovo, Instituto Superiore Di Sanita, Rome, Italy, 906B, I07, 906, 350. I4A*

( $f$ ) Cultures assigned to subcluster IF

Corynebacterium equi; ATCC25694. Ic*

C. equi; ATCC25729; R.E.G.; NCrCI621. Ic*

C. equi; ATCC25734; R.E.G., N4219; NCTC4219. I $c^{*}$

Nocardia restrictus; ATCC257 I5; R.E.G., 545. I $c^{*}$

N. restrictus; ATCC25728; R.E.G., I256. I $c^{*}$

Proactinomyces restrictus; ATCC257I6; R.E.G., 566. Ic ${ }^{*}$

(g) Cultures assigned to subcluster $1 \mathrm{G}$

Corynebacterium fascians; $M$. Turner, Nottingham University, 39. ${ }_{14} \mathrm{E}^{*}$

Corynebacterium rubrum; ATCC25727; R.E.G., 1240. I $b^{*}$

Mycobacterium eos; ATCC25705; R.E.G., 462. I $b^{*}$

Mycobacterium rhodochrous; R.E.G., 1240. I4 D*

$M$. rhodochrous; R.E.G., 8139. $14 \mathrm{E}^{*}$

$M$. rhodochrous; ATCC25723; R.E.G., 1054. $1 b^{*}$

Mycobacterium rubrum; ATCC25702; R.E.G., 384. I $b^{*}$

Mycobacterium sp.; ATCC25736; R.E.G.; NCTC8139. I $b^{*}$

Nocardia globerula; ATCC25714; R.E.G., 544. I $b^{*}$

Nocardia rubropertincta; NCIB9664; ATCCI4352. I4D*

N. rubropertincta; V. B. D. Skerman, Queensland University, $134 . \quad 14 \mathrm{D}^{*}$

Proactinomyces globerula; ATCC257I0; R.E.G., 494. I $b^{*}$

P. globerula; ATCC257I1; R.E.G., 495 . I $b^{*}$

'rhodochrous'; ATCC25669. I $b^{*}$

'rhodochrous'; ATCC25670. I $b^{*}$

'rhodochrous'; ATCC25671. $1 b^{*}$

'rhodochrous'; ATCC25672. I $b^{*}$

'rhodochrous'; ATCC25673. $1 b^{*}$

'rhodochrous'; ATCC25674. $1 b^{*}$

'rhodochrous'; ATcC25675. I $b^{*}$

'rhodochrous'; ATCC25676. I $b^{*}$

'rhodochrous'; АTCC25678. I $b^{*}$

'rhodochrous'; ATCC25679. I $b^{*}$

'rhodochrous'; ATCC2568I. I $b^{*}$

'rhodochrous'; ATCC25682. I $b^{*}$

'rhodochrous'; ATCC25683. I $b^{*}$

'rhodochrous'; ATCC25684. I $b^{*}$

'rhodochrous'; ATCC25687. I $b^{*}$

'rhodochrous'; ATCC25688. I $b^{*}$

'rhodochrous'; ATCC25689. I $b^{*}$

'rhodochrous'; ATCC25699. I $b^{*}$

'rhodochrous'; ATCC25685. I $b^{*}$

(h) Cultures assigned to subcluster $\mathbf{I H}$

Jensenia canicruria; NCIB8147. 14D*

$J$. canicruria; M. Turner, 29. 14D*

Mycobacterium rhodochrous, R.E.G., 1256. I4D*

M. rhodochrous; R.E.G., 1293S. I4D*

$M$. rhodochrous; R.E.G., 1257. 14D*

M. rhodochrous; R.E.G., 1293R. 14D* 


\section{Table I (cont.)}

N62 M. rhodochrous; R.E.G., 768. 14D*

N63 M. rhodochrous; R.E.G., 463. 14D*

N64 M. rhodochrous; R.E.G., 417; ATCC9356. $14 \mathrm{D}^{*}$

N65 M. rhodochrous; R.E.G., A7698; ATCC7698. I4D*

NI08 M. rhodochrous; R.E.G., A4277; ATCC4277. I4D*

N109 M. rhodochrous; R.E.G., 494. 14D*

NI48 Nocardia corallina; M. Turner, 83. 14D*

NI 1 Nocardia erythropolis; NCIB9158; ATCC4277. Type strain. 14D*

N23 N. erythropolis; CCM277; ATCC4277. I4D*

N209 N. erythropolis; J. E. Thiemann, Lepetit S.p.A., Milan, Italy, A2. I4D*

NI2 Nocardia globerula; NCIB9I 59; ATCC19370. Type strain. 14D*

N38 Nocardia opaca; NCIB9409. I4D*

N25 Proactinomyces globerulus; сСм279. 14D*

(i) Cultures assigned to subcluster II

N443 Nocardia rhodnii; P. Hill, Edinburgh University, A I

N444 N. rhodnii; P. Hill, A/O

N445 N. rhodnii; P. Hill, в/O; NCIBI I 279

N446 N. rhodnii; P. Hill, B/1

(j) Cultures assigned to subcluster $\mathbf{I} \mathbf{J}$

N650 Rhodococcus coprophilus; T. J. Rowbotham, Bradford University, cuB628

N65I $R$. coprophilus; T. J. Rowbotham, CUBII 8

N652 R. coprophilus; T. J. Rowbotham, N38

N653 R. coprophilus; T. J. Rowbotham, NI9

(k) Cultures assigned to cluster I

N663 Gordona aurantiaca; NCTC1074I. Type strain

N66I Gordona bronchialis; H. Mordarska, T2; M. Tsukamura, 3411

N10 Nocardia aurantia; NCIB9557; ATCCI 2674. I4E*

N452 Nocardia corallina; R. Bönicke, SN530I

N647 Nocardia kirovani; G. Michel, Lyons University, IMI 374

NI24 Nocardia opaca; CBS330.6I. $14 \mathrm{E}^{*}$

NI25 Nocardia opaca; CBS33I.6I. 14E*

$\mathrm{N} 7 \quad$ Nocardia restrictus; NCIBI0027. $14 \mathrm{E}^{*}$

(l) 'Markers' assigned to cluster 2

M12 Mycobacterium aurum; ATCC23366. Type strain

M158 Mycobacterium diernhoferi; ATCC19340. Type strain

M3 Mycobacterium flavescens; ATCC14474. Type strain

M93 Mycobacterium fortuitum; ATCC684I. Type strain

MI7 Mycobacterium parafortuitum; ATCC19686. Type strain

M6 Mycobacterium peregrinum; ATCC23023. Type strain

M98 Mycobacterium phlei; ATCCII758. Type strain

MIOI Mycobacterium smegmatis; ATCCI 1468. Type strain

MII Mycobacterium thermoresistibile; ATCC19527. Type strain

M37 Mycobacterium vaccae; ATCC15483. Type strain

$(m)$ 'Markers' assigned to cluster 3

NI3 Nocardia asteroides; NCTC8595; ATCC 14759

N100 N. asteroides; R.E.G., 652

NIO5 N. asteroides; R.E.G., 9969; ATCC9969

$\mathrm{N} 233 \quad N$. asteroides; R. Olds, Cambridge University, CN750

N317 N. asteroides; ATCC19247. Type strain

N14 Nocardia brasiliensis; NCTCI0300; ATCC19295

N48 N. brasiliensis; R.E.G., 744. ATCC9I 295

N3I I N. brasiliensis; F. Mariat, Institut Pasteur, Paris, 768

N312 N. brasiliensis; F. Mariat, 337

N318 N. brasiliensis; ATCC19296. Type strain

N36 Nocardia caviae; NCTCI934; ATCC 14629. Type strain

N23I N. caviae; R. Olds, CN749

N3I3 N. caviae; F. Mariat, $75 \mathrm{I}$

N562 N. caviae; D. Frey, Royal North Shore Hospital, The Institute of Medical Research, N.S.W., Australia, I91 I

$\mathrm{N} 563 \quad$ N. caviae; D. Frey, I9I 2

* Phena recovered by Goodfellow (I97I) or by Goodfellow et al. (1974).

+ Superior letters preceding laboratory numbers indicate triplicate $(a, b)$ or duplicate (c to i) cultures.

M, N, R, laboratory numbers. ATCC, American Type Culture Collection, Rockville, Maryland, U.S.A. CBS, Centraal Bureau voor Schimmelcultures, Baarn, The Netherlands. CCM, Czechoslovak Collection of Microorganisms, Brno, Czechoslovakia. LA, Institut d'Hygiene, Lausanne, Switzerland. NCiB, National Collection of Industrial Bacteria, Aberdeen, Scotland. NCTC, National Collection of Type Cultures, London. 
Seven-day-old YEA cultures were used to inoculate the test media and tests were read after 7 and 14 days incubation at $30^{\circ} \mathrm{C}$. The media and methods have been described previously (Goodfellow, I97I; Lacey \& Goodfellow, 1975). Inhibition and nutritional tests were performed in divided dishes (Sneath \& Stevens, 1967), degradation studies in Petri dishes and physiological tests in tubes. Cultures grown on modified Sauton's medium were analysed for the presence of lipids characteristic for Nocardia (lipid LCN-A) (Mordarska, Mordarski \& Goodfellow, 1972). These lipids have been found to be free, short-chain mycolic acids (Goodfellow et al., 1973; Minnikin, Patel \& Goodfellow, 1974; Alshamaony et al., 1976a, b).

Coding of data. Nearly all of the characters existed in one of two mutually exclusive states and were scored plus $(+)$ or minus $(-)$. Qualitative multistate characters, such as pigmentation and colony elevation, were scored plus $(+)$ for the character state shown and minus $(-)$ for the alternatives; quantitative multistate characters, for example allantoinase and urease production, were scored by the additive method of Sokal \& Sneath (1963). The binary data were entered on standard IBM punched cards.

Computer analyses. Data were analysed using the matching coefficient $S_{S M}$ (Sokal \& Michener, 1958) and sor ted similarity matrices were obtained using the unweighted average linkage cluster analysis technique (Sneath \& Sokal, 1974). The mean intragroup and intergroup similarity values of the defined clusters were printed after clustering. Vigour and pattern statistics were also calculated (Sneath, I968).

\section{RESULTS}

\section{Clustering of the strains using the $S_{S M}$ coefficient and average linkage technique}

The test strains were recovered in three clusters defined at the 75 to $80 \%$ similarity level (S level) (Fig. I). One hundred and fifty-two strains provisionally assigned to the genus Gordona or the 'rhodochrous' complex grouped into cluster I; the mycobacteria and nocardiae grouped into clusters 2 and 3 respectively (Fig. I; Table I). Most of the cultures in cluster I fell into one of Io subclusters: IA to IJ (Fig. I; Table I). The mean intragroup similarity of each cluster and subcluster and the corresponding intergroup similarities are shown in Tables 2 and 3. The three clusters are well separated and mean intragroup similarities are high.

\section{Cluster I}

Subcluster IA contains 49 strains (Table I $a$ ) including the earliest described rhodochrous strain, Rhodococcus rhodochrous (N54 and R9).

Subcluster IB contains two strains (Table $\mathrm{I} b$ ) which share a high similarity to those in subcluster IA (Fig. I).

Subcluster IC contains 8 gordonae and two strains received as Nocardia corallina (Table I c). This taxon exhibits some structure; Gordona bronchialis strains (N654, N660) and two of the G. terrae strains (N656, N662) can be distinguished from each other and from the remaining strains in the subcluster (Fig. 1). Two Gordona strains did"not group in the subcluster; G. aurantiaca (N663) is only marginally included in cluster I but G. bronchialis (N66I) shows a high affinity to both subclusters IA and IC.

Subclusters ID and IE share a high intergroup similarity $(\geqslant 85 \%)$ and contain strains received as Nocardia pellegrino; the former also includes six strains labelled N. rubra (Table I $d, e$ ). 


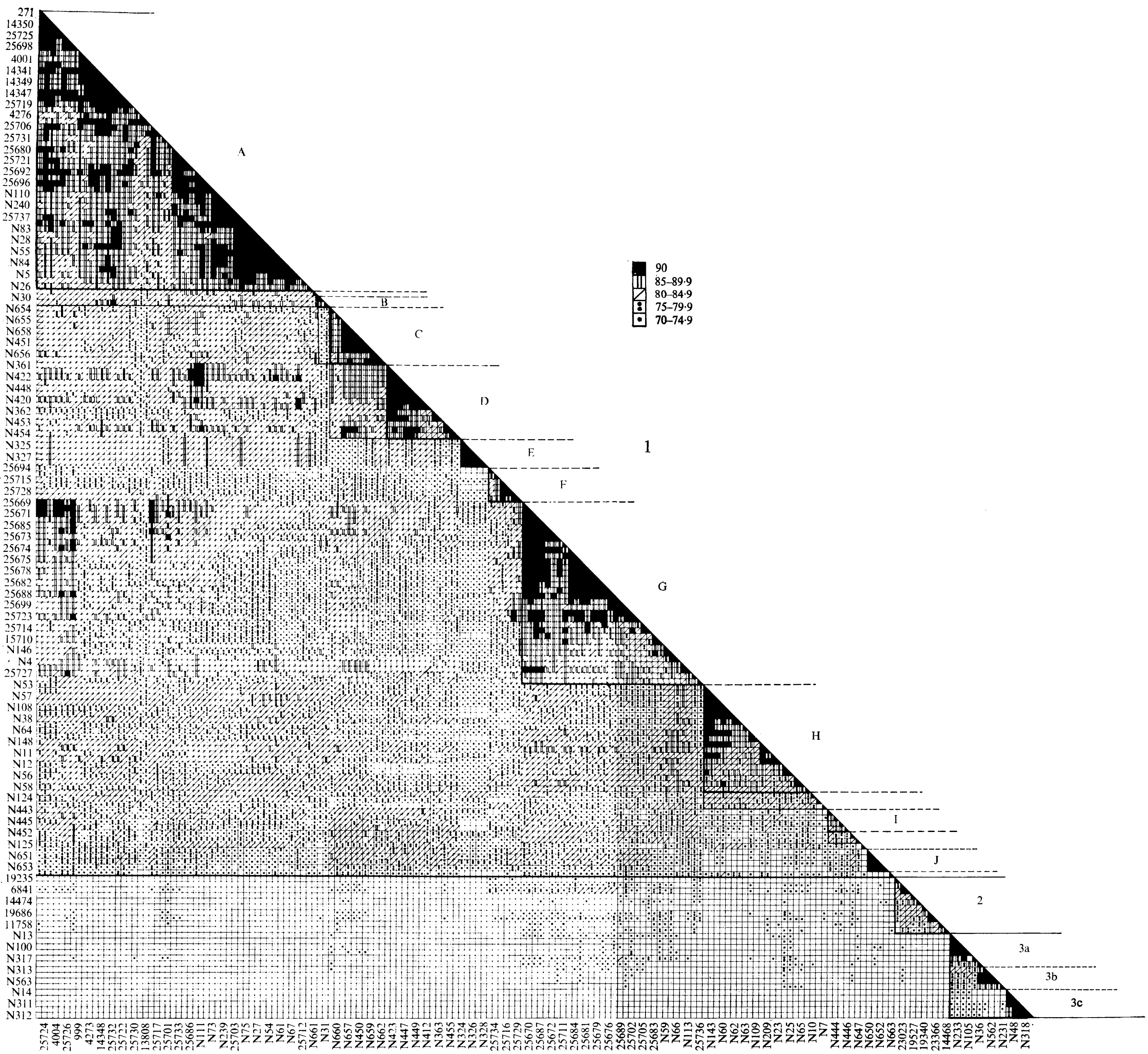

Fig. I. Matching matrix of the 177 test cultures based on 92 unit characters.

(Facing p. 104) 


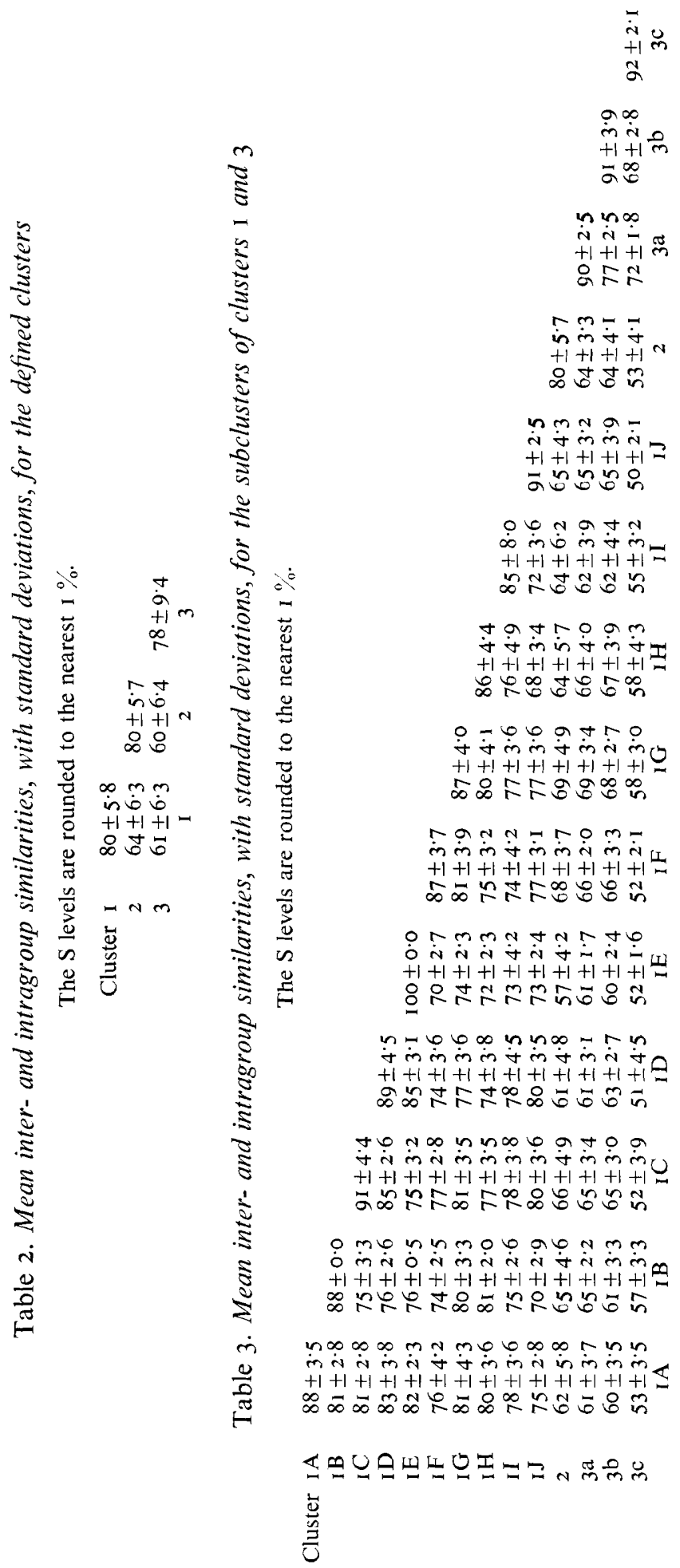


Table 4. Distribution of 17 characters with the greatest resolving power for the three clusters

Results indicate the percentage frequency of positive characters.

\begin{tabular}{|c|c|c|c|}
\hline Character & $\begin{array}{l}\text { Cluster I } \\
*(\mathrm{I} 52)\end{array}$ & $\begin{array}{l}\text { Cluster } 2 \\
\text { (IO) }\end{array}$ & $\begin{array}{l}\text { Cluster } 3 \\
\text { (15) }\end{array}$ \\
\hline \multicolumn{4}{|l|}{ Staining and colony morphology: } \\
\hline Strongly acid-fast & 0 & 100 & 0 \\
\hline Mycelium formed & 100 & 0 & 100 \\
\hline Aerial hyphae moderate to abundant & 0 & o & 100 \\
\hline Margin entire & 83 & 100 & 0 \\
\hline Elevation convex & $8 \mathrm{I}$ & 100 & 0 \\
\hline Colonies pink, red, orange & 85 & 10 & 67 \\
\hline Diffusible exopigment & o & $\circ$ & 100 \\
\hline \multicolumn{4}{|l|}{ Growth on sole carbon source: } \\
\hline Ethanol & 94 & 20 & 0 \\
\hline$p$-Hydroxybenzoic acid & 70 & 0 & 0 \\
\hline Sodium octanoate & 74 & 40 & 0 \\
\hline Testosterone & 70 & 0 & 67 \\
\hline Growth at $10^{\circ} \mathrm{C}$ & 73 & 0 & 13 \\
\hline \multicolumn{4}{|l|}{ Growth in the presence of: } \\
\hline $\begin{array}{l}0.3 \%(v / v) \text { Phenylethanol } \\
7.0 \%(w / v) \text { Sodium chloride }\end{array}$ & 81 & o & 20 \\
\hline $7.0 \%(w / v)$ Sodium chloride & 77 & o & 27 \\
\hline Susceptibility to to i.u. penicillin & $9 \mathrm{r}$ & 0 & 34 \\
\hline Allantoinase weak & 15 & o & 100 \\
\hline LCN-A present & 100 & 0 & 100 \\
\hline
\end{tabular}

Subcluster IF is composed of three strains received as Corynebacterium equi, and three as Nocardia restrictus or Proactinomyces restrictus (Table I $f$ ).

Subcluster IG contains 32 strains carrying a number of different genus and species names (Table I $g$ ).

Subcluster IH accommodates I9 strains also received under a variety of names (Table $\mathrm{I} h$ ).

Subcluster II is composed of four strains of Nocardia rhodnii (Table $\mathrm{I} i$ ).

Subcluster IJ contains four strains received as Rhodococcus coprophilus (Table I $j$ ).

The remaining strains classified in cluster $\mathrm{I}$ are listed in Table $\mathrm{I} k$.

\section{Clusters 2 and 3}

Cluster 2 contains the marker strains of Mycobacterium and cluster 3 the nocardiae (Table $\mathrm{I} l, m)$; the latter are distributed into subclusters $(a, b$ and $c$ ) representing Nocardia asteroides, N. caviae and $N$. brasiliensis respectively (Fig. I).

\section{Reproducibility of results}

Since some identical strains (Table $\mathrm{I}$ ) were received from different sources it was possible to get an approximate estimate of the experimental test error. Triplicate cultures were examined simultaneously but some of the duplicate cultures were studied on separate occasions in two different laboratories. As the tests, incubation conditions and scoring procedures were standardized, both intra-laboratory and inter-laboratory errors could be estimated. With cultures examined at the same time, the probability $(p)$ of an erroneous 
result averaged $3.7 \%$ which is equal to an observed $S_{S M}$ value of around $92 \%$ between duplicate cultures. With cultures studied on two different occasions, the $p$ value was $8 \cdot 1 \%$.

\section{Clustering of strains using vigour and pattern statistics}

The percentage dissimilarity $\left(D_{T}\right)$ between strains can be divided into vigour $\left(D_{V}\right)$ and pattern $\left(D_{P}\right)$ components (Sneath, 1968). The former expresses the difference between strains in total metabolic activity, as measured by the number of positive reactions. The pattern difference reflects which particular tests give positive results and tries to make allowances for differences in growth rates, periods of incubation and similar factors which would otherwise be included in the overall dissimilarity.

The removal of the vigour component from total dissimilarities did not have any effect on the distribution of strains to the three main clusters and only marginally influenced the composition of the rhodochrous subclusters. Five strains (R35, R55, R56, R58, N59) originally classified in subcluster $I G$ were regrouped in subcluster IA and one strain (R74) from the latter was reclassified in subcluster IG. Three strains (R30, N66, NI46) recovered in subcluster IG were allocated to subcluster I $\mathrm{H}$.

Characters useful for separation of the 'rhodochrous' taxon from Mycobacterium and Nocardia

Seventeen characters were chosen as having the greatest resolving power for the separation of cultures assigned to the three clusters (Table 4 ).

\section{Properties and identification of the rhodochrous subclusters}

In the phenotypic characterization of the rhodochrous strains several characters were found to have a discriminating value. This was apparent when the frequency of each test which was positive in each of the subclusters had been calculated (Table 5). Fourteen characters were chosen as having the greatest resolving power for the differentiation of the rhodochrous subclusters (Table 6). Most of the subclusters could be distinguished by six or more characters; only subclusters I D and IE were difficult to separate.

\section{DISCUSSION}

The most stable classifications are those in which the relationships between taxa are consistent when they are based on different kinds of taxonomic criteria, and the degree of confidence that can be placed in a classification is a reflection of the congruence found between the different types of information. Numerical taxonomy and DNA:DNA reassociation are two of the more powerful tools in modern taxonomy; however, at present it is not possible to formally equate homology with similarity values or to objectively relate either of them to taxonomic rank. Nevertheless, there seems to be good agreement between nucleotide sequence homology and numerical phenetic data in a number of genera (Sneath, 1972; Colwell et al., 1974; Staley \& Colwell, 1973) and in some actinomycete taxa (Gross \& Wayne, 1970; Mordarski et al., 1976).

In phenetic taxonomy there is always a danger that results are influenced by differences in growth rates and cultural conditions (Sneath, 1968) and by test errors and the lack of reproducibility of tests; numerical taxonomy has highlighted this (Sneath, 1972, 1976; Sneath \& Johnson, 1972). The phena in the present study were based on pattern differences because removal of the vigour component only marginally affected the clustering of the test strains. Test errors between laboratories tend to be greater than those within laboratories 


\section{Table 5. Percentage frequencies of positive characters found in the subclusters of cluster $\mathrm{I}$}

Character

Colony morphology:

Aerial hyphae sparse

Margin entire

Margin filamentous

Elevation convex

Elevation irregular

Colonies white

Colonies pink, red, orange

Degradation of:

Adenine

Allantoin, weak

Tyrosine

Urea, weak

Urea, strong

k

Subcluster

Growth on sole carbon source $(1 \%, w / v)$ :
Glycerol

Inositol

Inulin

Maltose

Mannitol

Rhamnose

Salicin

Sorbitol

Trehalose
Growth on sole carbon source $(0.1 \%, w / v)$ :

Acetamide

p-Cresol

$m$-Hydroxybenzoic acid

$p$-Hydroxybenzoic acid

Pimelic acid

Sebacic acid

Sodium adipate

Sodium benzoate

Sodium butyrate

Sodium citrate

Sodium fumarate

Sodium gluconate

Sodium lactate

Sodium malate

Sodium octanoate

Sodium pyruvate

Sodium succinate

Sodium tartrate

Testosterone

L-Tyrosine

Growth on sole carbon/nitrogen source:

Acetamide

Growth at:

$$
\begin{aligned}
& 10{ }^{\circ} \mathrm{C} \\
& 40^{\circ} \mathrm{C} \\
& 45^{\circ} \mathrm{C}
\end{aligned}
$$

\begin{tabular}{|c|c|c|c|c|c|c|c|c|c|}
\hline $\begin{array}{c}\text { IA } \\
*(49)\end{array}$ & $\begin{array}{l}\text { IB } \\
(2)\end{array}$ & $\begin{array}{c}\mathrm{IC} \\
\text { (I0) }\end{array}$ & $\begin{array}{l}\text { ID } \\
\text { (13) }\end{array}$ & $\begin{array}{l}\mathrm{IE} \\
(5)\end{array}$ & $\begin{array}{l}\text { IF } \\
(6)\end{array}$ & $\begin{array}{r}\text { IG } \\
(32)\end{array}$ & $\begin{array}{c}\text { IH } \\
\text { (I9) }\end{array}$ & $\begin{array}{l}\text { II } \\
(4)\end{array}$ & $\begin{array}{l}\text { I J } \\
(4)\end{array}$ \\
\hline I 6 & 0 & 0 & 46 & 100 & 0 & 3 & 48 & 0 & 25 \\
\hline 98 & 100 & 40 & 23 & 0 & 100 & 100 & 100 & 100 & 0 \\
\hline 2 & 0 & 0 & 78 & 100 & 0 & 0 & 0 & 0 & 100 \\
\hline 82 & 100 & 60 & 100 & 100 & 0 & 90 & 85 & 100 & 100 \\
\hline 18 & 0 & 0 & 0 & 0 & 0 & 9 & I I & 0 & 0 \\
\hline 2 & 0 & 0 & 8 & 0 & 17 & 9 & 64 & 25 & 0 \\
\hline 98 & 100 & 100 & 92 & 100 & 83 & 90 & 32 & 75 & 100 \\
\hline 64 & 100 & 0 & I 5 & 100 & IOO & 0 & 95 & 0 & 0 \\
\hline 2 & 0 & 0 & 0 & 0 & 0 & 6 & 69 & 0 & 0 \\
\hline 96 & 50 & 0 & 85 & 100 & 0 & 9 & 69 & 100 & 0 \\
\hline 56 & 100 & 100 & 85 & 100 & 100 & 96 & 85 & 100 & 100 \\
\hline 56 & 50 & IO & 0 & 0 & 83 & 78 & 85 & 50 & 0 \\
\hline
\end{tabular}

/v):

$\begin{array}{llllllllll}100 & 100 & 100 & 85 & 100 & 100 & 96 & 100 & 50 & 0\end{array}$

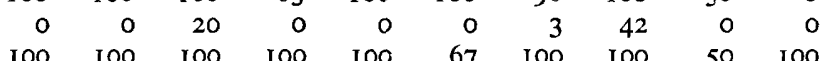

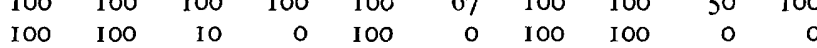

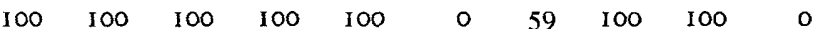

$\begin{array}{rrrrrrrrrr}0 & 0 & 20 & 0 & 0 & 0 & 0 & 0 & 0 & 0 \\ 22 & 50 & 0 & 0 & 0 & 17 & 0 & 80 & 0 & 0 \\ 100 & 100 & 80 & 92 & 100 & 0 & 59 & 95 & 100 & 0\end{array}$

$\begin{array}{llllllllll}96 & 100 & 100 & 69 & 100 & 0 & 90 & 100 & 50 & 0\end{array}$

$\begin{array}{rrrrrrrrrr}72 & 100 & 60 & 78 & 100 & 33 & 68 & 90 & 100 & 0 \\ 22 & 0 & 20 & 8 & 100 & 0 & 0 & 0 & 25 & 0 \\ 96 & 100 & 100 & 92 & 100 & 0 & 90 & 21 & 50 & 50 \\ 80 & 100 & 0 & 100 & 100 & 17 & 6 & 0 & 0 & 100 \\ 86 & 100 & 70 & 100 & 100 & 83 & 56 & 80 & 50 & 50 \\ 68 & 50 & 100 & 100 & 100 & 0 & 12 & 64 & 75 & 100 \\ 88 & 100 & 100 & 85 & 100 & 0 & 90 & 100 & 50 & 25 \\ 100 & 50 & 100 & 100 & 100 & 33 & 90 & 85 & 100 & 100 \\ 96 & 50 & 100 & 100 & 100 & 67 & 37 & 5 & 100 & 100 \\ 100 & 100 & 100 & 100 & 100 & 33 & 100 & 90 & 100 & 100 \\ 96 & 100 & 70 & 92 & 100 & 50 & 84 & 85 & 25 & 25 \\ 96 & 100 & 100 & 100 & 100 & 100 & 81 & 100 & 75 & 75 \\ 46 & 100 & 80 & 46 & 0 & 0 & 28 & 100 & 100 & 25 \\ 92 & 100 & 30 & 23 & 100 & 67 & 22 & 90 & 25 & 0 \\ 100 & 100 & 100 & 100 & 100 & 100 & 87 & 100 & 100 & 0 \\ 92 & 0 & 100 & 92 & 100 & 83 & 68 & 37 & 100 & 100 \\ 100 & 100 & 30 & 54 & 100 & 100 & 93 & 100 & 0 & 100 \\ 98 & 100 & 100 & 100 & 100 & 100 & 93 & 100 & 100 & 0 \\ 0 & 0 & 20 & 23 & 100 & 0 & 0 & 0 & 0 & 0 \\ 90 & 0 & 90 & 92 & 100 & 50 & 10 & 95 & 0 & 100 \\ 88 & 50 & 20 & 92 & 100 & 50 & 90 & 5 & 100 & 0 \\ & & & & & & & & & \\ 56 & 0 & 40 & 69 & 0 & 50 & 53 & 53 & 100 & 0 \\ & & & & & & & & & \\ 96 & 100 & 0 & 15 & 100 & 100 & 87 & 85 & 0 & 25 \\ 100 & 100 & 100 & 100 & 100 & 100 & 96 & 90 & 0 & 75 \\ 26 & 0 & 0 & 0 & 0 & 0 & 3 & 5 & 0 & 0\end{array}$


Table 5 (cont.)

Growth in the presence of:

$0.001 \%(w / v)$ Crystal violet $0.0001 \%(\mathrm{w} / \mathrm{v})$ Crystal violet $0.1 \%(\mathrm{w} / \mathrm{v})$ Phenol

$0.3 \%$ (v/v) Phenylethanol $0.01 \%(w / v)$ Sodium azide $0.02 \%(w / v)$ Sodium azide $5.0 \%(w / v)$ Sodium chloride $7.0 \%$ (w/v) Sodium chloride

Susceptibility to Io i.u. penicillin

\begin{tabular}{|c|c|c|c|c|c|c|c|c|c|}
\hline \multicolumn{10}{|c|}{ Subcluster } \\
\hline I A & IB & IC & ID & IE & IF & IG & $1 \mathrm{H}$ & I I & I J \\
\hline 96 & 50 & 100 & 100 & 100 & 100 & 93 & 42 & IOO & IOO \\
\hline 62 & 0 & 100 & 85 & 100 & 100 & 68 & 5 & 50 & 100 \\
\hline 96 & IOO & 100 & 92 & 100 & 33 & 68 & 42 & 25 & 100 \\
\hline 98 & 0 & 90 & 100 & 100 & 67 & $8 I$ & 58 & 0 & 75 \\
\hline 56 & o & IOO & 85 & 100 & 100 & 8 I & 80 & 100 & 75 \\
\hline I 8 & 0 & 90 & 100 & IOO & 50 & I 6 & 64 & 25 & 25 \\
\hline 98 & 0 & 100 & 100 & 100 & 100 & 96 & 95 & 100 & 100 \\
\hline 76 & 0 & 100 & 92 & 100 & 50 & 84 & 74 & IOO & 100 \\
\hline 92 & IOO & 40 & 100 & IOO & 50 & 96 & 100 & 100 & 100 \\
\hline IOO & 100 & 80 & 100 & 100 & 100 & 96 & 90 & 100 & 100 \\
\hline 82 & 50 & 0 & 23 & 0 & 0 & 0 & 5 & 0 & 0 \\
\hline 4 & 0 & IO & 15 & 100 & 17 & 0 & 0 & 0 & 0 \\
\hline
\end{tabular}

Enzymic activity:

Nitrate reduction $m$-Nitrophenoloxidase $p$-Nitrophenoloxidase

* Number of cultures analysed is given in parentheses.

No strains of subclusters IA to IJ utilized adonitol, arabinose, cellobiose, galactose, lactose, melezitose, raffinose or xylose as sole carbon sources; nor trimethylenediamine or serine as sole carbon and nitrogen sources. None degraded allantoin (strong), casein, elastin, hypoxanthine, Tween 20, Tween 40, Tween 60. None were acid-fast, nor produced diffusible pigment. Nearly all strains formed mycelium. All utilized ethanol, fructose, mannose, sucrose, sodium acetate and sodium propionate as sole carbon sources; and contained LCN-A.

Table 6. Distribution of 14 characters with the greatest resolving power for the Io subclusters of cluster $\mathrm{I}$

Results indicate the percentage frequency of positive characters.

Character

Degradation of:

Adenine

Tyrosine

Growth on sole carbon source:

Glycerol $(\mathrm{I} \%, \mathrm{w} / \mathrm{v})$

Maltose $(1 \%, w / v)$

Mannitol $(1 \%, w / v)$

Sorbitol $(1 \%, w / v)$

Trehalose $(1 \%, w / v)$

p-Cresol $(0.1 \%$, w/v)

$m$-Hydroxybenzoic acid $(0 . \mathrm{I} \%, \mathrm{w} / \mathrm{v}) 8$

Sodium pyruvate $(0.1 \%, \mathrm{w} / \mathrm{v})$

Testosterone $(0.1 \%, \mathrm{w} / \mathrm{v})$

Growth at $10{ }^{\circ} \mathrm{C}$

Growth in the presence of:

$0.0001 \%(\mathrm{w} / \mathrm{v})$ Crystal violet $0.02 \%(w / v)$ Sodium azide
Subcluster

\begin{tabular}{|c|c|c|c|c|c|c|c|c|c|}
\hline $\begin{array}{c}\text { I A } \\
*(49)\end{array}$ & $\begin{array}{l}\text { I B } \\
\text { (2) }\end{array}$ & $\begin{array}{l}\mathrm{IC} \\
\text { (IO) }\end{array}$ & $\begin{array}{l}\text { ID } \\
\text { (I3) }\end{array}$ & $\begin{array}{l}\text { IE } \\
\text { (5) }\end{array}$ & $\begin{array}{l}\text { IF } \\
(6)\end{array}$ & $\begin{array}{l}\mathrm{IG} \\
(32)\end{array}$ & $\begin{array}{l}\mathbf{I H} \\
\text { (I } 9)\end{array}$ & $\begin{array}{l}\text { I I } \\
\text { (4) }\end{array}$ & $\begin{array}{l}\text { I J } \\
(4)\end{array}$ \\
\hline 64 & 100 & 0 & 15 & roo & 100 & o & 95 & 0 & 0 \\
\hline 96 & 50 & 0 & 85 & 100 & 0 & 9 & 69 & 100 & 0 \\
\hline 100 & 100 & 100 & 85 & 100 & 100 & 96 & 100 & 50 & 0 \\
\hline 100 & 100 & IO & 0 & 100 & 0 & 100 & 100 & 0 & 0 \\
\hline 100 & 100 & 100 & 100 & 100 & 0 & 59 & 100 & 100 & 0 \\
\hline 100 & 100 & 80 & 92 & 100 & 0 & 5 & 95 & 100 & 0 \\
\hline 96 & 100 & 100 & 69 & 100 & 0 & 90 & 100 & 50 & 0 \\
\hline 96 & 100 & 100 & 92 & 100 & 0 & 90 & $2 \mathrm{I}$ & 50 & 50 \\
\hline 80 & 100 & 0 & 100 & 100 & 17 & 6 & 0 & 0 & 100 \\
\hline 100 & IOO & 30 & 54 & 100 & 100 & 93 & 100 & 0 & 100 \\
\hline 90 & 0 & 90 & 92 & 100 & 50 & 10 & 95 & 0 & 100 \\
\hline 96 & IOO & 0 & 15 & 100 & 100 & 87 & 85 & 0 & 25 \\
\hline 62 & 0 & 100 & 85 & 100 & 100 & 68 & 5 & 50 & 100 \\
\hline 18 & 0 & 90 & 100 & IOO & 50 & 16 & 64 & 25 & 25 \\
\hline
\end{tabular}

* Number of cultures analysed is given in parentheses. 
(Sneath, 1976), a trend which was again apparent in the present investigation where the probabilities of error were $8.1 \%$ and $3.7 \%$ respectively. Experimental error on this scale can be accommodated in numerical taxonomic surveys (Sneath, 1976) though errors over $10 \%$ are likely to degrade taxonomic structure (Sneath \& Johnson, 1972).

Our results, in accordance with the conclusions of earlier studies (Cerbón, I967; Bradley, 1971; Goodfellow, 1971; Tacquet et al., 1971 ; Kubica et al., 1972; Goodfellow et al., 1973, 1974) show that the 'rhodochrous' complex forms a taxon equivalent in rank to the genera Mycobacterium and Nocardia. Less attention has been paid to the relationships between rhodochrous strains and coryneform bacteria but it seems that the 'rhodochrous' complex can be distinguished from taxa such as Arthrobacter, Corynebacterium and Brevibacterium linens (Bousfield, 1972; Jones, 1975; Bousfield \& Goodfellow, 1976). The recovery of the gordonae in the 'rhodochrous' complex is in agreement with the results of Tsukamura (1974, 1975) and lends support to his view that gordonae and rhodochrous strains be classified in a single taxon. The new data, based on test strains representing rhodochrous phena recovered in earlier studies, make it timely to evaluate the taxonomic status of the 'rhodochrous' complex and of the phena within it.

Subcluster IA is substantially the same as Nocardia rubra (Bradley, 1971), phenon I4C (Goodfellow, 197I), Gordona rhodochroa (Tsukamura, 197I) and phenon I $a$ (Goodfellow et al., 1974). It contains strains carrying a variety of names, and to those listed in Table I can be added Nocardia blackwellii, N. globerula and N. opaca (Bradley, 1971) and N. salmonicolor, Proactinomyces corallinus, $P$. luteus, $P$. phenoli and P. ruber (Goodfellow, I97I). The type strains of Gordona rosea (R6) and Gordona rubropertincta (Tsukamura, 1973) were recovered in subcluster IA and phenon Ia (Goodfellow et al., 1974) respectively. The oldest name borne by any strain in subcluster IA was Rhodococcus rhodochrous.

Representatives of subcluster IA and the equivalent phena form a distinct serological group (Goodfellow et al., 1974; Ridell, 1974), contain free mycolic acids with 38 to 48 carbon units (Alshamaony et al., 1976a), have menaquinones with eight isoprene units and one hydrogenated double bond as the prevalent type (Collins et al., 1977), and form a DNA homology group which can be distinguished from similar groups of rhodochrous strains (Clark et al., I97 ; Mordarski et al., 1976, I977). They have a DNA base composition within the range 62 to $69 \mathrm{~mol} \%$ GC (Mordarski et al., 1976, 1977). Subcluster IB, phenon I4B (Goodfellow, I97I), contains only two strains (Table $\mathrm{I} b$ ) which should be classified in subcluster IA. Tsukamura (I973) classified rhodochrous strain N3I as Gordona rhodochroa and Mordarski et al. (1977) found that subclusters IA and IB formed a single DNA homology group. Subcluster IB strains share a high similarity to subcluster IA strains (Fig. I) and failure to recover them in the same subcluster can be attributed to small test and sampling errors. Subcluster IA contains two strains which originally carried the epithet rhodochrous: ATCCI3808 (N54) (R. rhodochrous Zopf) and N3I (Micrococcus rhodochrous Overbeck); the former is the type strain of Mycobacterium rhodochrous (Gordon, 1966).

The gordonae in subcluster IC can be divided into three groups which contain the type strains of Gordona bronchialis, G. rubra and G. terrae respectively (Fig. I). These taxa have a similar but narrower DNA base composition range than subcluster I A strains and form DNA homology groups that can be distinguished from each other and from other rhodochrous homology groups (Mordarski et al., 1976, 1977). Gordonae can be separated from most other rhodochrous strains by their antibiotic sensitivity pattern (Goodfellow \& Orchard, 1974), their possession of mycolic acids with 52 to 66 carbon units (Alshamaony et al., $1976 b$ ) and their possession of menaquinones with nine isoprene units and one hydro- 
genated double bond as the prevalent type (Collins et al., 1977). Nocardia kirovani (N647) contains free mycolic acids with between 59 and 65 carbon units (Alshamaony et al., $1976 \mathrm{~b}$ ). The relationship between $N$. kirovani, Gordona aurantiaca and rhodochrous strains needs to be examined in more detail.

Nocardia pellegrino strains form a good taxon on the basis of biochemical (Juhasz \& Bönicke, 1965; Pietkiewicz, Andrzejewski \& Mordarska, 1973), chemical (Mordarska et al., 1973) and phage susceptibility studies (Pietkiewicz et al., 1974). Representative strains form a distinct DNA homology group and have a DNA base composition range of 65 to 69 mol \% GC (Mordarski et al., I976), can be recognized serologically (Ridell, 1974), and contain menaquinones with eight isoprene units and one hydrogenated double bond as the prevalent type (Collins et al., 1977). Strains received as $N$. pellegrino were originally classified as phenon 14A (Goodfellow, 197I), and this taxon was stable when duplicate strains from different sources were added to it (Goodfellow et al., 1972). In the present study, based on fewer unit characters, the same duplicate strains were recovered in subclusters ID and IE respectively, a result evidently due to sampling error. The two subclusters share a high intergroup similarity (Table 3), cannot readily be distinguished (Table 5) and subsequently are treated as one taxon. Subcluster ID contains six strains received as Nocardia rubra (Tsukamura, 197I), one of which (N36r) was recently described as the type strain of Gordona lentifragmenta (Tsukamura et al., I975).

Subcluster IF contains strains received as Corynebacterium equi, Nocardia restrictus and Proactinomyces restrictus and is identical to phenon I $c$ (Goodfellow et al., 1974). Gordon (I966) studied all of these strains, except R39, and classified them with rhodochrous strains which do not produce acid from mannitol or sorbitol. The subcluster contains the type strain of C. equi (NCTCI621) which is said to ferment glucose (Davis \& Newton, 1969; Rogosa et al., 1974). The type strain does not grow anaerobically and produces acid from glucose oxidatively (Gordon, I966; D. Jones, personal communication; M. Goodfellow, unpublished data). On thin-layer chromatography $C$. equi strains produce a mycolic acid spot with a low but variable $R_{F}$ value (Goodfellow, Collins \& Minnikin, 1976), and on this basis form a group intermediate between many corynebacteria and rhodochrous strains. They also contain menaquinones with eight isoprene units and one hydrogenated double bond as the prevalent type (Collins et al., 1977).

Subcluster IG contains a few strains originally classified in phena ${ }_{14} \mathrm{D}$ and ${ }_{14} \mathrm{E}$ (Goodfellow, 1971) but is substantially the same taxon as phenon I $b$ (Goodfellow et al., I974). Representative strains have a DNA base composition of 62 to $67 \mathrm{~mol} \%$ GC (Mordarski et al., 1977), contain mycolic acids with a similar chain length to those in nocardiae (Alshamaony et al., 1976a; D. E. Minnikin, M. Goodfellow \& L. Alshamaony, unpublished data) and may contain characteristic precipitinogens (Goodfellow et al., 1974).

Subcluster IH corresponds to Nocardia erythropolis (Bradley, 197I), phenon I4D (Goodfellow, 197I) and cluster F3 (Jones, 1975). The taxon contains strains received under a variety of names (Table $\mathrm{I} h$ ) to which can be added Nocardia corallina, $N$. canicruria, N. coeliaca, N. erythropolis and N. opaca (Bradley, 1971), Jensenia canicruria, Nocardia lutea and Proactinomyces canicruria (Goodfellow, 1971) and Nocardia calcarea (NCIB8863) (Jones, 1975). Representative strains form a DNA homology group (Clark et al., 197I; Bradley \& Huitron, 1973; Bradley, Brownell \& Clark, I973; Bradley \& Mordarski, 1976), have a DNA base composition of 6I to $67 \mathrm{~mol} \%$ GC (Bradley, r97I ; Mordarski et al., 1977), are susceptible to phage $\phi \mathrm{EC}$ (Bradley, 1971), contain mycolic acids with 36 to 48 carbon units (Alshamaony et al., I976a), and have menaquinones with eight isoprene units and one hydrogenated double bond as the prevalent type (Collins et al., 1977). 
Subcluster II contains strains, labelled Nocardia rhodnii, isolated from the intestinal flora of the blood sucking anthropod Rhodnius prolixus Ståh. There is a consistent association of strains labelled $N$. rhodnii with Rhodnius prolixus and evidence that the relationship is a symbiotic one (Cross et al., 1976); however, the identification of the microsymbiont has not always been based on critical taxonomic criteria. An authentic strain of $N$. rhodnii (Erikson, 1935) produced aerial hyphae and was reduced to a synonym of Nocardia asteroides (Gordon \& Mihm, I957); it was recovered in the Nocardia asteroides cluster by Goodfellow (I97I). Strain N443 has a DNA base composition of $66 \mathrm{~mol} \% \mathrm{GC}$ (Mordarski et al., I977).

Subcluster I $\mathbf{J}$ contains representatives of Rhodococcus coprophilus, a taxon proposed (Rowbotham \& Cross, 1976) to accommodate bacteria with the trivial name Lspi (large, spored, pink, irregular) and briefly described by Willoughby (I969). Representative strains have a DNA base composition of 60 to $64 \mathrm{~mol} \% \mathrm{GC}$ (Mordarski et al., I977).

On the basis of the evidence presented we recommend that the 'rhodochrous' complex be recognized as a genus in its own right. We agree with those (Tsukamura, 1974; Bousfield \& Goodfellow, 1976; Rowbotham \& Cross, 1976) who consider that the name Rhodococcus Zopf I89I has priority over Proactinomyces (Jensen I93I) Bradley \& Bond 1974, Jensenia Bisset \& Moore I950 and Gordona Tsukamura I97I. An amended description of the genus and of nine of the species within it is given below. A tenth species, Rhodococcus coprophilus, has been described by Rowbotham \& Cross (1977).

Tsukamura (1974) proposed the names Rhodococcus aurantiacus, $R$. bronchialis, $R$. rhodochrous, $R$. rosea, $R$. rubropertinctus and $R$. terrae for the Gordona species: G. aurantiaca Tsukamura \& Mizuno 197I, G. bronchialis Tsukamura 1971, G. rhodochroa (Zopf I89I) Tsukamura 1973, G. rosea (Grotenfelt I889) Tsukamura 1973, G. rubropertincta (Hefferan 1904) Tsukamura 1973 and $G$. terrae Tsukamura I97I respectively. At present there are insufficient data to recognize $R$. rosea and $R$. rubropertinctus as good taxospecies and they are reduced to synonyms of $R$. rhodochrous. Rhodococcus coprophilus forms a good taxospecies. However, further work needs to be done to determine the relationships between ' $R$. aurantiacus' and other nocardioform taxa. Of the remaining taxa proposed, one is a new species and the others carry new combinations.

A name has to be found for the taxon containing strains of Nocardia pellegrino and $N$. rubra. The epithet pellegrino has not been validly published and $N$. rubra (Kruse I896) Chalmers \& Christopherson I9I6 was considered (Tsukamura, I97I, I975) to have priority for a group of organisms carrying the labels Nocardia convoluta, Nocardia erythropolis, Nocardia globerula, Nocardia lutea, Nocardia polychromogenes and Nocardia rubropertincta. This taxon was subsequently transferred to the genus Gordona as G. lentifragmenta (Tsukamura et al., 1975), the combination Gordona rubra having already been used (Tsukamura, I971). Gordona rubra Tsukamura I97I was subsequently considered to be identical to Gordona rubropertincta (Tsukamura, 1973) and the latter was given priority. We propose, therefore, that the taxon containing strains received as Nocardia pellegrino and Nocardia rubra be called Rhodococcus rubrus.

We consider Gordona rubra Tsukamura 197I to be a good species on both phenetic and genetic grounds (Mordarski et al., I976). In the present study the taxon contained strains received as Nocardia corallina and did not cluster with the type strains of Gordona rubropertincta Tsukamura I973. The Nocardia corallina strains conformed to Hefferan's delineation of Bacillus mycoides corallinus (see Gordon \& Mihm, 1957), and the name Rhodococcus corallinus is proposed for the taxon.

The combination Nocardia restrictus has not been validly published, and Corynebacterium 
equi Magnusson 1923 has priority over Proactinomyces restrictus (Turfitt, I944). The name Rhodococcus equi is proposed for subcluster IF.

In selecting a name for subcluster IG the following were considered: Corynebacterium fascians (Tilford 1936) Downson 1942, Corynebacterium rubrum Crowle 1962, Mycobacterium rubrum Söhngen I9I3, Nocardia globerula (Gray 1928) Waksman \& Henrici 1948, Nocardia rubropertincta (Hefferan 1904) Waksman \& Henrici 1948, and Proactinomyces globerulus Reed 1939. Nocardia rubropertincta has priority over the other validly published names and the name Rhodococcus rubropertinctus is proposed for the taxon.

Subcluster $\mathrm{I} H$ contains strains carrying a number of names, and includes the type strains of Nocardia erythropolis (Gray \& Thornton 1928) Waksman \& Henrici 1948 and Nocardia globerula (Gray 1928) Waksman \& Henrici 1948. Nocardia erythropolis is considered to have priority and the name Rhodococcus erythropolis is proposed for the taxon.

The strains classified in subcluster II were received as Nocardia rhodnii. Although the type strain of $N$. rhodnii (Erikson, 1935) Waksman \& Henrici 1948 has been reduced to a synonym of Nocardia asteroides (Gordon \& Mihm, 1957; Goodfellow, 197I), the name Rhodococcus rhodnii is retained for this taxon.

DESCRIPTION OF GENUS AND ENCOMPASSED SPECIES

Emendation of Rhodococcus Zopf I89I

(Rho.do.coc'cus. Gr.n. rhodum the rose; Gr.n. coccus a grain or berry; M.L.neut.n. Rhodococcus a red coccus.)

The important characteristics of the genus based on the literature descriptions of the 'rhodochrous' taxon (Gordon \& Mihm, 1957; Gordon, 1966; Tsukamura, 1971; Cross \& Goodfellow, 1973; Bradley \& Bond, 1974; Goodfellow \& Orchard, 1974; Lacey \& Goodfellow, 1975), and on our own data, are as follows. Rhodococci are aerobic, Gram-positive actinomycetes that are pleomorphic but often form a primary mycelium that soon fragments into irregular elements. When inoculated into a fresh nutrient medium, the rod-shaped and coccoid cells give rise to a primary mycelium. Rhodococci are non-motile, may be partially acid-fast and do not produce endospores or conidia, though some strains show a few feeble aerial hyphae. Colonies may be rough, smooth, mucoid or mycobacterial-like and are usually pigmented buff, pink, orange or red, though colourless variants occur. Most strains grow quickly on standard media at $30^{\circ} \mathrm{C}$ but some require vitamin' $\mathrm{B}_{1}$ (thiamin) for growth.

Rhodococci reduce nitrate but do not degrade casein, elastin or hypoxanthine. Acid is formed from fructose, glucose, maltose and mannose, but not from dulcitol, lactose, $\alpha$-methyl-D-glucoside or raffinose. Ethanol, fructose, glucose, mannose, sucrose, acetate, butyrate, fumarate and propionate are utilized as sole sources of carbon for energy and growth but adonitol, arabinose, cellobiose, erythritol, galactose, lactose, melezitose, raffinose or xylose are not. Most strains are sensitive to lysozyme, benzylpenicillin, cephaloridine, erythromycin, gentamycin, neomycin and tobramycin. They do not exhibit arylsulphatase activity.

The cell wall peptidoglycan contains meso-diaminopimelic acid, arabinose and galactose (wall type IV) (Mordarska et al., 1973; Goodfellow et al., I974; Rowbotham \& Cross, 1976). Rhodococci contain mycolic acids and LCN-A (Mordarska et al., 1972; Alshamaony et al., I $976 a, b)$ and the GC content of their DNA ranges from 59 to $69 \mathrm{~mol} \%\left(T_{m}\right.$, buoyant density) (Mordarski et al., 1976, 1977).

Species have a wide distribution and are found in soil (Tsukamura, 1971), in the intes- 
tinal flora of insects, in cow dung, manured meadows and fresh water habitats (Cross \& Rowbotham, 1974; Cross et al., 1976), and are often isolated from enrichments with both aliphatic and aromatic hydrocarbons (Fredricks, 1967; Raymond, Jamison \& Hudson, 1967).

The type species is Rhodococcus rhodochrous (Zopf I89I) Tsukamura 1974.

Because Rhodococcus is aerobic, has fragmenting vegetative mycelium, type IV walls and mycolic acids, the genus should be classified in the family Nocardiaceae (Lechevalier \& Lechevalier, 1970; Prauser, 1970; Cross \& Goodfellow, 1973). The species descriptions given below do not include characters described as characteristic of the genus.

\section{Emendation of Rhodococcus rhodochrous}

(Overbeck I891; Zopf I89I; Gordon \& Mihm 1957) Tsukamura 1974

The species description is based on our own data and that of earlier studies (Goodfellow, 197I ; Goodfellow et al., I974; Tsukamura et al., 1975).

Morphology. On glucose yeast extract agar (GYEA), the primary mycelium soon fragments into rods and cocci. Rough, orange to red colonies are formed on GYEA, Sauton's agar and egg media.

Temperature requirements. Growth at to to $40{ }^{\circ} \mathrm{C}$.

Enzymic activity. Allantoinase, nicotinamidase and pyrazinamidase negative. $\alpha$-Esterase negative; $\beta$-esterase weakly positive.

Degradation tests. Tyrosine but not $p$-aminosalicylate (PAS) is degraded.

Fermentation studies. Acid is not produced from adonitol, arabinose, cellobiose, ethanol, galactose, glycogen, inositol, inulin, mannitol, melezitose, rhamnose, sorbitol, sucrose, trehalose or xylose.

Sole carbon requirements. Growth on glycerol, inulin, maltose, mannitol, sorbitol, adipate, benzoate, $p$-cresol, $m$-hydroxybenzoic acid, $p$-hydroxybenzoic acid, malate, octanoate, sebacic acid, succinate, testosterone and pyruvate as sole sources of carbon for energy and growth, but not on glycogen, rhamnose, malonate or tartrate.

Sole carbon and nitrogen sources. Growth on glucosamine and L-glutamate, but not on ethanolamine, serine or trimethylenediamine.

Lipid characters. The organisms contain free mycolic acids with 38 to 48 carbon units (Alshamaony et al., 1976a), have menaquinones with eight isoprene units and one hydrogenated double bond as the prevalent type (Collins et al., 1977), but do not possess mycobactins or nocobactins (Ratledge \& Patel, 1976a).

$G+C$ content of DNA. The $\mathrm{G}+\mathrm{C}$ content is $62 \mathrm{~mol} \%$ by $T_{m}$ for the type strain and 62 to $69 \%$ for the other strains tested (Mordarski et al., I976, I977).

Type strain. The type strain is N54 (= ATCCI $3808=\mathrm{R}$. E. Gordon 372$)$.

Further comments. The group was described previously as Nocardia rubra (Bradley, 1971), phenon I4C (Goodfellow, I97I), Gordona rhodochroa (Tsukamura, I97I), and phenon I $a$ (Goodfellow et al., 1974).

Rhodococcus bronchialis (Tsukamura 1971) emend. Tsukamura 1974

The species description is based on our own data and that of earlier studies (Tsukamura, 1971; Tsukamura et al., I975).

Morphology. Slightly acid-fast, rod-shaped bacteria which produce rough, pink to red colonies on GYEA, Sauton's agar and egg media.

Temperature requirements. Growth at 28 to $40^{\circ} \mathrm{C}$. 
Enzymic activity. Acetamidase, nicotinamidase and pyrazinamidase positive; allantoinase negative. $\alpha$-Esterase negative; $\beta$-esterase and acid phosphatase positive.

Degradation tests. Neither tyrosine nor PAS is degraded.

Fermentation studies. Acid is produced from inositol and trehalose, but not from galactose, rhamnose, sorbitol or xylose.

Sole carbon requirements. Growth on glycerol, inositol, inulin, mannitol, sorbitol, trehalose, adipate, benzoate, $p$-cresol, malate, octanoate, pimelic acid, propan-I-ol, propane-I,2-diol, pyruvate, sebacic acid, succinate and testosterone as sole sources of carbon for energy and growth, but not on arabinose, $m$-hydroxybenzoic acid, malonate or rhamnose.

Sole carbon and nitrogen sources. Growth on acetamide and L-glutamate, but not on benzamide, ethanolamine, serine or trimethylenediamine.

Lipid characters. The organisms contain free mycolic acids with 56 to 66 carbon units (Alshamaony et al., 1976b), and have menaquinones with nine isoprene units and one hydrogenated double bond as the prevalent type (Collins et al., 1977).

$G+C$ content of DNA. The $\mathrm{G}+\mathrm{C}$ content is $65 \mathrm{~mol} \%$ by $T_{m}$ for the type strain and $63 \%$ for the other strain tested (Mordarski et al., 1976).

Distribution. Isolated from sputum of patients with pulmonary disease.

Type strain. The type strain is $\mathrm{N} 654(=\mathrm{ATCC} 25592=\mathrm{NCTC} 10667)$.

Rhodococcus corallinus (Bergey et al. 1923) comb. nov.

The species description is based on our own data and that of Tsukamura (I971).

Morphology. Slightly acid-fast, rod-shaped bacteria which produce rough, orange to red colonies on GYEA, Sauton's agar and egg media.

Temperature requirements. Growth at 28 to $40^{\circ} \mathrm{C}$.

Enzymic activity. Urease and allantoinase positive; acetamidase, nicotinamidase and pyrazinamidase negative.

Degradation tests. Neither tyrosine nor PAS is degraded.

Fermentation studies. Acid is produced from mannitol and sorbitol, but not from arabinose, galactose, inositol, rhamnose or xylose.

Sole carbon requirements. Growth on glycerol, inulin, mannitol, sorbitol, trehalose, adipate, benzoate, butane-2,3-diol, citrate, p-cresol, malate, octanoate, pimelic acid, propan-I-ol, sebacic acid, succinate and testosterone as sole sources of carbon? for energy and growth, but not on inositol, rhamnose, salicin, $m$-hydroxybenzoic acid, malonate or propane-1,2-diol.

Sole carbon and nitrogen sources. Growth on L-glutamate and ethanolamine, but not on acetamide, benzamide, serine or trimethylenediamine.

Lipid characters. The organisms contain free mycolic acids with 52 to 64 carbon units (Alshamaony et al., 1976b).

$G+C$ content of DNA. The $\mathrm{G}+\mathrm{C}$ content is $67 \mathrm{~mol} \%$ by $T_{m}$ for the type strain and for the other strain tested (Mordarski et al., 1976).

Distribution. Soil.

Type strain. The type strain is $\mathrm{N} 657(=\mathrm{ATCC} 25593=\mathrm{NCTC10668})$.

Rhodococcus erythropolis (Gray \& Thornton 1928) comb. nov.

The species description is based on our own data and that of earlier studies (Goodfellow, 197I ; Jones, 1975). 
Morphology. On GYEA, the primary mycelium soon fragments into rods and cocci. Rough, orange to red colonies are formed on GYEA and Sauton's agar.

Temperature requirements. Growth at 4 to $40^{\circ} \mathrm{C}$.

Enzymic activity. Urease and phosphatase positive.

Degradation tests. Adenine is degraded.

Fermentation studies. Acid is produced from glycerol, sorbitol, sucrose and trehalose, but not from adonitol, arabinose, cellobiose, galactose, glycogen, \inulin, melezitose, rhamnose or xylose.

Sole carbon requirements. Growth on glycerol, inulin, maltose, mannitol, sorbitol, trehalose, adipate, gluconate, lactate, malate, pyruvate, sebacic acid, succinate and testosterone as sole sources of carbon for energy and growth, but not on glycogen, inositol, rhamnose, benzamide, $m$-hydroxybenzoic acid, malonate or tartrate.

Sole carbon and nitrogen sources. No growth on serine or trimethylenediamine.

Lipid characters. The organisms contain ,ree mycolic acids with 36 to 48 carbon units (Alshamaony et al., 1976a), have menaquinones with eight isoprene units and one hydrogenated double bond as the prevalent type (Collins et al., 1977) but do not possess mycobactins or nocobactins (Ratledge \& Patel, $1976 a$ ).

$G+C$ content of $D N A$. The $\mathrm{G}+\mathrm{C}$ content is $67 \mathrm{~mol} \%$ by $T_{m}$ for the type strain, and $6 \mathrm{I}$ to $67 \%$ for the other strains tested (Bradley, I97I ; Mordarski et al., 1977).

Distribution. Soil.

Type strain. The type strain is NII (= ATCC4277 = NCIB9158).

Further comments. The group was described previously as Nocardia erythropolis (Adams et al., 1970; Bradley, 197I), phenon I4D (Goodfellow, 1971), and cluster F3 (Jones, 1975). Jensenia canicruria Bisset \& Moore 1950, Nocardia calcarea Metcalf \& Brown 1957, and Nocardia globerula (Gray I928) Waksman \& Henrici 1948 are synonyms of $R$. erythropolis.

Rhodococcus equi (Magnusson I923) comb. nov.

The species description is based on our own data and that of earlier studies (Gordon, 1966; Goodfellow et al., 1974).

Morphology. Produces filaments on GYEA which soon fragment into rods and coccoid elements. On GYEA, smooth, shiny orange to red colonies with entire margins are formed. Some cultures produce abundant slime which may drip on to the cover of inverted Petri dishes during incubation.

Temperature requirements. Growth at Io to $40{ }^{\circ} \mathrm{C}$.

Enzymic activity. Urease positive.

Degradation tests. Adenine but not tyrosine is degraded.

Fermentation studies. Acid is not produced from arabinose, inositol, mannitol, rhamnose or sorbitol.

Sole carbon requirements. Growth on glycerol, lactate, malate, pyruvate and succinate as sole sources of carbon for energy and growth but not on inositol, maltose, mannitol, rhamnose, sorbitol, trehalose, butane-2,3-diol, p-cresol, mucate, oxalate, pimelic acid, sebacic acid or tartrate.

Sole carbon and nitrogen sources. No growth on serine or trimethylenediamine.

Lipid characters. The organisms contain free mycolic acids (LCN-A), and have menaquinones with eight isoprene units and one hydrogenated double bond as the prevalent type (Collins et al., I977).

$G+C$ content of DNA. A G $+\mathrm{C}$ content of $58 \cdot 5 \mathrm{~mol} \%$ has been reported (Hill, I966). 
Distribution. Originally isolated from pneumonia in foals.

Type strain. The type strain is R7I (= ATCC25729 = NCTCI62I $)$.

\section{Rhodococcus rhodnii sp. nov.}

(rhod'ni.i. M.L.masc.n. Rhodnius generic name of the reduvid bug; M.L.gen.n. rhodnii of Rhodnius.)

The species description is based on our own data.

Morphology. On GYEA, the primary mycelium soon fragments into rods and cocci. Colonies are rough, have entire margins and are usually red.

Temperature requirements. Growth at 25 to $37^{\circ} \mathrm{C}$.

Enzymic activity. Urease positive.

Degradation tests. Tyrosine but not adenine is degraded.

Sole carbon requirements. Growth on mannitol, sorbitol, acetamide, adipate, benzoate, gluconate, malate, octanoate, succinate and L-tyrosine as sole sources of carbon for energy and growth, but not on inositol, maltose, rhamnose, salicin, $m$-hydroxybenzoic acid, pyruvate, tartrate or testosterone.

Sole carbon and nitrogen sources. Growth on acetamide, but not on serine or trimethylenediamine.

Lipid characters. The organisms contain free mycolic acids.

$G+C$ content of $D N A$. The $\mathrm{G}+\mathrm{C}$ content of strain $\mathrm{N} 443$ is $66 \mathrm{~mol} \%$ by $T_{m}$ (Mordarski et al., 1977).

Distribution. Isolated from the reduvid bug Rhodnius prolixus.

Type strain. The type strain is N445 (NCIBI I 279).

Rhodococcus rubrus (Kruse 1896) Tsukamura I97I comb. nov.

The species description is based on our own data and that of Tsukamura et al. (I975).

Morphology. On GYEA, the primary mycelium soon fragments into rods, short rods and cocci. Rough, pink to red colonies are formed on GYEA, Sauton's agar and egg media.

Temperature requirements. Growth at 28 to $40{ }^{\circ} \mathrm{C}$.

Enzymic activity. $\alpha$ - and $\beta$-esterase negative. Galactosidase and acid phosphatase negative; acetamidase and urease positive.

Degradation tests. Tyrosine is degraded.

Fermentation studies. Acid is produced from mannitol and sorbitol, but not from inositol, rhamnose or trehalose.

Sole carbon requirements. Growth on glycerol, inulin, mannitol, sorbitol, trehalose, adipate, benzoate, butan-I-ol, 2-methylpropan-I-ol, citrate, $p$-cresol, $m$-hydroxybenzoic acid, $p$-hydroxybenzoic acid, malate, malonate, octanoate, pimelic acid, propan-I-ol, propane-r,2-diol, pyruvate, sebacic acid, succinate, testosterone and L-tyrosine as sole sources of carbon for energy and growth but not on inositol, salicin or rhamnose.

Sole carbon and nitrogen sources. Growth on acetamide, glutamate, glucosamine and ethanolamine, but not on benzamide, serine or trimethylenediamine.

Lipid characters. The organisms contain free mycolic acids with 38 to 50 carbon units (Alshamaony et al., I976a), have menaquinones with eight isoprene units and one hydrogenated double bond as the prevalent type (Collins et al., 1977), but do not possess mycobactins or nocobactins (Ratledge \& Patel, I976a). 
$G+C$ content of $D N A$. The $\mathrm{G}+\mathrm{C}$ content is 65 to $69 \mathrm{~mol} \%$ by $T_{m}$ for the strains tested (Mordarski et al., 1976, 1977).

Type strain. The type strain is N36I (= M. Tsukamura M-I).

Rhodococcus rubropertinctus (Hefferan 1904) comb. nov.

The species description is based on our own data and that of Goodfellow et al. (I974). Morphology. On GYEA, the primary mycelium soon fragments into rods and cocci. Colonies are pink to red, rough with entire margins.

Temperature requirements. Growth at io to $40{ }^{\circ} \mathrm{C}$.

Enzymic activity. Urease positive; allantoinase and benzamidase negative.

Degradation tests. Neither adenine nor tyrosine is degraded.

Sole carbon requirements. Growth on glycerol, inulin, maltose, trehalose, adipate, $p$-cresol, pyruvate, sebacic acid, succinate and L-tyrosine as sole sources of carbon for energy and growth, but not on inositol, rhamnose, salicin, benzamide, $m$-hydroxybenzoic acid, tartrate or testosterone.

Sole carbon and nitrogen sources. No growth on serine or trimethylenediamine.

Lipid characters. The organisms contain free mycolic acid (LCN-A type asteroides), but do not possess mycobactins or nocobactins (Ratledge \& Patel, 1976a).

$G+C$ content of $D N A$. The $\mathrm{G}+\mathrm{C}$ content is 62 to $67 \mathrm{~mol} \%$ by $T_{m}$ for the strains tested (Mordarski et al., 1976, 1977).

Type strain. The type strain is $\mathrm{N} 4$ (= ATCCI $4352=$ NCIB9664).

Further comments. The group was described previously as phenon $\mathrm{i} b$ (Goodfellow et al., 1974).

\section{Rhodococcus terrae (Tsukamura 197I) emend. Tsukamura 1974}

The species description is based on our own data and that of earlier studies (Tsukamura, 1971; Tsukamura et al., 1975).

Morphology. Slightly acid-fast, rod-shaped bacteria which produce rough, pink to orange colonies on GYEA, Sauton's agar and egg media.

Temperature requirements. Growth at 28 to $40{ }^{\circ} \mathrm{C}$.

Enzymic activity. Urease, allantoinase, nicotinamidase, pyrazinamidase positive; acetamidase and acid phosphatase negative. $\beta$-Esterase positive; $\alpha$-esterase negative.

Degradation tests. Neither tyrosine nor PAS is degraded.

Fermentation studies. Acid is produced from mannitol, rhamnose, sorbitol and trehalose but not from arabinose, galactose, inositol or xylose.

Sole carbon requirements. Growth on glycerol, inulin, mannitol, rhamnose, sorbitol, trehalose, adipate, benzoate, $p$-cresol, malate, octanoate, pimelic acid, sebacic acid and succinate as sole sources of carbon for energy and growth, but not on inositol, butane2,3-diol, malonate or propane-I,2-diol.

Sole carbon and nitrogen sources. Growth on L-glutamate and ethanolamine, but not on acetamide, benzamide or serine.

Lipid characters. The organisms contain free mycolic acids with 52 to 64 carbon units (Alshamaony et al., 1976b) and have menaquinones with nine isoprene units and one hydrogenated double bond as the prevalent type (Collins et al., 1977).

$G+C$ content of DNA. The G+C content is $64 \mathrm{~mol} \%$ by $T_{m}$ for the type strain and $69 \%$ for the other strain tested (Mordarski et al., 1976).

Distribution. Soil.

Type strain. The type strain is $\mathrm{N} 659$ (= ATCC25594 = NCTC10669). 
The authors thank their colleagues who kindly provided bacterial cultures (see Table I) and are particularly indebted to Drs I. J. Bousfield and T. Cross for helpful discussions. This investigation was supported, in part, by Medical Research Council grant G970/I r2/B.

\section{REFERENCES}

Adams, M. M., Adams, J. N. \& Brownell, G. H. (1970). The identification of Jensenia canicruria Bisset and Moore as a mating type of Nocardia erythropolis (Gray and Thornton) Waksman and Henrici. International Journal of Systematic Bacteriology 20, 133-I48.

Alshamaony, L., Goodfellow, M. \& Minnikin, D. E. (I976a). Free mycolic acids as criteria in the classification of Nocardia and the 'rhodochrous' complex. Journal of General Microbiology 92, 1 88-199.

Alshamaony, L., Goodfellow, M., Minnikin, D. E. \& Mordarska, H. (I976b). Free mycolic acids as criteria in the classification of Gordona and the 'rhodochrous' complex. Journal of General Microbiology 92, I $83-187$.

Bergey, D. H., Harrison, F. C., Breed, R. S., Hammer, B. W. \& Huntoon, F. M. (1923). Bergey's Manual of Determinative Bacteriology, Ist edn. Baltimore: Williams \& Wilkins.

BisseT, K. A. \& MoORE, F. W. (1950). Jensenia, a new genus of the Actinomycetales. Journal of General Microbiology 4, 280 .

Bousfield, I. J. (1972). A taxonomic study of some coryneform bacteria. Journal of General Microbiology 7I, $44 I-455$.

BOUSFIELD,'I. J. \& Goodfellow, M. (I976). The 'rhodochrous' complex and its relationships with allied taxa. In The Biology of the Nocardiae, pp. 39-65. Edited by M. Goodfellow, G. H. Brownell and J. A. Serrano. London: Academic Press.

BRADLEY, S. G. (I97I). Criteria for definition of Mycobacterium, Nocardia and the 'rhodochrous' complex. Advancing Frontiers of Plant Sciences 28, 349-362.

BRADLEY, S. G. ( I 973). Relationships among mycobacteria and nocardiae based upon deoxyribonucleic acid reassociation. Journal of Bacteriology $113,645-65 \mathrm{r}$.

BRAdley, S. G. \& Bond, J. S. (1974). Taxonomic criteria for mycobacteria and nocardiae. Advances in Applied Microbiology 18, I3I-I90.

Bradley, S. G. \& Huitron, M. E. (I973). Genetic homologies among nocardiae. Developments in Industrial Microbiology 14, I89-199.

BRADley, S. G. \& MORDARSKI, M. (1976). Association of polydeoxyribonucleotides of deoxyribonucleic acids from nocardioform bacteria. In The Biology of the Nocardiae, pp. 310-336. Edited by M. Goodfellow, G. H. Brownell and J. A. Serrano. London: Academic Press.

Bradley, S. G., Brownell, G. H. \& Clark, J. E. (1973). Genetic homologies among nocardiae and other actinomycetes. Canadian Journal of Microbiology 19, I007-10I4.

Brownell, G. H., Adams, J. N. \& Bradley, S. G. (1967). Growth and characterization of nocardiophages for Nocardia canicruria and Nocardia erythropolis mating types. Journal of General Microbiology 47, $247-256$.

CERBón, J. (1967). Taxonomic analysis of Nocardia. Revista latino-americana de microbiologia y parasitologia $9,65-68$.

Chalmers, A. J. \& Christopherson, J. B. (i9i6). A Sudanese actinomycosis. Annals of Tropical Medicine and Parasitology 10, 223-282.

Clark, J. E., Brownell, G. H. \& Bradley, S. G. (I971). Analysis of compatible nocardiae by DNA:DNA hybridization. Bacteriological Proceedings, 38.

Collins, M. D., Pirouz, T., Goodfellow, M. \& Minnikin, D. E. (1977). Distribution of menaquinones in actinomycetes and corynebacteria. Journal of General Microbiology Ioo (in the Press).

Colwell, R. R., Johnson, R., Wan, L., Lovelace, T. E. \& Brenner, D. J. (1974). Numerical taxonomy and deoxyribonucleic acid reassociation in the taxonomy of some Gram-negative fermentative bacteria. International Journal of Systematic Bacteriology 24, 422-433.

Cross, T. \& Goodfellow, M. (1973). Taxonomy and classification of the actinomycetes. In Actinomycetales: Characteristics and Practical Importance, Society for Applied Bacteriology Symposium Series No. 2, pp. I I-I I 2. Edited by G. Sykes and F. A. Skinner. London: Academic Press.

Cross, T. \& RowbOTHAM, T. J. (1974). The isolation, enumeration and identification of nocardioform bacieria in clean and polluted streams and in lake waters and mud. In Proceedings of the First International Conference on the Biology of the Nocardiae, pp. 48-49. Georgia, U.S.A.: McGowen Printing Co.

Cross, T., Rowbotham, T. J., Mishustin, E. N., Tepper, E. Z., Portaels, F. P., SchaAl, K. O. \& BickenBACH, H. B. (1976). The ecology of nocardioform actinomycetes. In The Biology of the Nocardiae, pp. 337-37I. Edited by M. Goodfellow, G. H. Brownell and J. A. Serrano. London: Academic Press.

Crowle, A. J. (1962). Corynebacterium rubrum nov. spec., a Gram-positive non acid-fast bacterium of unusually high lipid content. Antonie van Leeuwenhoek 28, I 82-192. 
Davis, G. H. G. \& Newton, K. G. (1969). Numerical taxonomy of some named coryneform bacteria. Journal of General Microbiology 56, 195-2 I4.

Downson, W. J. (1942). On the generic name of the gram-positive bacterial plant pathogens. Transactions of the British Mycological Society 25, 3 I I-3I4.

ERIKSON, D. (1935). The pathogenic aerobic organisms of the Actinomyces group. Medical Research Council (British) Special Report Series 203, 5-6I.

FredRICKS, K. M. (1967). Products of the oxidation of $n$-decane by Pseudomonas aeruginosa and $M y c o-$ bacterium rhodochrous. Antonie van Leeuwenhoek 33, 4I-48.

Goodfellow, M. (I97I). Numerical taxonomy of some nocardioform bacteria. Journal of General Microbiology 69, 33-80.

Goodfellow, M. \& ORChard, V. A. (1974). Antibiotic sensitivity of some nocardioform bacteria and its value as a criterion for taxonomy. Journal of General Microbiology 83, 375-387.

Goodfellow, M., Fleming, A. \& SaCKIN, M. J. (1972). Numerical classification of 'Mycobacterium' rhodochrous and Runyon's group IV mycobacteria. International Journal of Systematic Bacteriology 22, 8I-96.

Goodfellow, M., Minnikin, D. E., Patel, P. V. \& Mordarska, H. (i973). Free nocardomycolic acids in the classification of nocardias and strains of the 'rhodochrous' complex. Journal of General Microbiology 74, I $85-188$.

Goodfellow, M., Lind, A., Mordarska, H., Pattyn, S. \& Tsukamura, M. (1974). A co-operative numerical analysis of cultures considered to belong to the 'rhodochrous' taxon. Journal of General Microbiology 85, 29I-302.

Goodfellow, M., Collins, M. D. \& Minnikin, D. E. (1976). Thin-layer chromatographic analysis of mycolic acid and other long-chain components in whole-organism methanolysates of coryneform and related taxa. Journal of General Microbiology 96, 35 I-358.

Gordon, R. E. (1966). Some strains in search of a genus - Corynebacterium, Mycobacterium, Nocardia or what? Journal of General Microbiology 43, 329-343.

Gordon, R. E. \& MiHM, J. M. (1957). A comparative study of some strains received as nocardiae. Journal of Bacteriology 73, I 5-27.

Gordon, R. E. \& Minm, J. M. (I959). A comparison of four species of mycobacteria. Journal of General Microbiology 21, 736-748.

Gordon, R. E. \& MikM, J. M. (I96I). The specific identity of Jensenia canicruria. Canadian Journal of Microbiology 7, I08-I I0.

Gray, P. H. H. (I928). The formation of indigotin from indol by soil bacteria. Proceedings of the Royal Society Bro2, 263-280.

Gray, P. H. H. \& Thornton, H. G. (I928). Soil bacteria that decompose certain aromatic compounds. Zentralblatt für Bakteriologie, Parasitenkunde, Infektionskrankheiten und Hygiene (Abteilung II) 73, 74-96.

Gross, N. M. \& WAYNE, L. G. (1970). Nucleic acid homology in the genus Mycobacterium. Journal of Bacteriology 104, 630-634.

Grotenfelt, G. (1889). Studien über die Zersetzungen der Milch. Fortschritte der Medizin 7, 4I-46.

HefFERAN, M. (I904). A comparative and experimental study of bacilli producing red pigment. Zentralblatt für Bakteriologie, Parasitenkunde, Infektionskrankheiten und Hygiene (Abteilung II) II, 397-404.

Hill, L. R. (I966). An index to deoxyribonucleic acid base compositions of bacterial species. Journal of General Microbiology 44, 4I9-437.

JenSEN, H. L. (I93I). Contributions to our knowledge of the Actinomycetales. II. The definition and subdivision of the genus Actinomyces, with a preliminary account of Australian soil actinomycetes. Proceedings of the Linnean Society of New South Wales 56, 345-370.

JONES, D. (I975). A numerical taxonomic study of coryneform and related bacteria. Journal of General Microbiology 87, 52-96.

Jones, L. A. \& BRADLEY, S. G. (I964). Relationships among streptomycetes, nocardiae, mycobacteria and other actinomycetes. Mycologia 56, 505-513.

Juhasz, S. E. \& BöNiCke, R. (1965). Mycobacterium oder Nocardia pellegrino? Beiträge zur Klinik der Tuberkulose und zur spezifischen Tuberkuloseforschung r30, I55-I69.

KruSE, W. (I896). Systematik der Streptothrickeen und Bakterien. In Die Mikroorganismen by C. Flugge, vol. 2 , pp. 48-66.

KubICA, G. P. ET AL. (1972). A co-operative numerical analysis of rapidly growing mycobacteria. Journal of General Microbiology 73, 55-70.

LACEY, J. \& GoODFEllow, M. (1975). A novel actinomycete from sugar-cane bagasse: Saccharopolyspora hirsuta gen. et sp. nov. Journal of General Microbiology 88, 75-85.

LecheVAlier, H. A. \& LecheVAlier, M. P. (I970). A critical evaluation of the genera of aerobic actinomycetes. In The Actinomycetales, pp. 393-405. Edited by H. Prauser. Jena: Gustav Fischer.

LeChevalier, M. P. \& LeChevalier, H. A. (I974). Nocardia amarae sp. nov., an actinomycete common in foaming activated sludge. International Journal of Systematic Bacteriology 24, 278-288.

Lind, A. \& Ridell, M. (1976). Serological relationships between Nocardia, Mycobacterium, Corynebacterium and the "rhodochrous' taxon. In The Biology of the Nocardiae, pp. 220-235. Edited by M. Goodfellow, G. H. Brownell and J. A. Serrano. London: Academic Press. 
MCClung, N. M. (1974). Bergey's Manual of Determinative Bacteriology, 8th edn. Edited by R. E. Buchanan and N. E. Gibbons. Baltimore: Williams \& Wilkins.

Magnusson, H. (I 923). Spezifische infektiose Pneumonie beim Fohlen. Ein neuer Eitererreger beim Pferde. Archiv für wissenschaftliche und praktische Tierheilkunde 50, 22-38.

Magnusson, M. (1962). Specificity of sensitins. III. Further studies on guinea pigs with sensitins of various species of Mycobacterium and Nocardia. American Review of Respiratory Diseases 86, 395-404.

Manion, R. E., Bradley, S. G., Zinneman, H. H. \& Hall, W. H. (I964). Interrelationships among mycobacteria and nocardiae. Journal of Bacteriology 87, 1056-1059.

MetCAlf, G. \& Brown, M. (I957). Nitrogen fixation by new species of Nocardia. Journal of General Microbiology I7, 567-572.

Minnikin, D. E., PAtel, P. \& Goodfellow, M. (1974). Mycolic acids of representative strains of Nocardia and the 'rhodochrous' complex. FEBS Letters 39, 322-324.

Mordarska, H., Mordarski, M. \& Goodfellow, M. (1972). Chemotaxonomic characters and classification of some nocardioform bacteria. Journal of General Microbiology 71, 77-86.

Mordarska, H., Mordarski, M. \& Pietkiewicz, D. (1973). Chemical analysis of hydrolysates and cell extracts of Nocardia pellegrino. International Journal of Systematic Bacteriology 23, 274-277.

Mordarski, M., Szyba, K., Pulverer, G. \& Goodfellow, M. (1976). Deoxyribonucleic acid reassociation in the classification of the 'rhodochrous' complex and allied taxa. Journal of General Microbiology 94, $235^{-245 .}$

Mordarski, M., Goodfellow, M., Szyba K., Pulverer, G. \& Tkacz, A. (i977). Classification of the 'rhodochrous' complex and allied taxa based upon deoxyribonucleic acid reassociation. International Journal of Systematic Bacteriology 27, 3I-38.

Overbeck, A. (I89I). Zur Kenntnis der Fettfarbstoff-Production bei Spaltpilzen. Nova acta Leopoldina 55, 399-416.

Pietkiewicz, D., Andrzejewski, J. \& Mordarska, H. (1973). Nocardia pellegrino: I. Versuch einer morphologischen und biochemischen Characteristik der Art. Zentralblatt für Bakteriologie 13, 171-I 72.

Pietkiewicz, D., Andrzejewski, J., Manowska, W. \& Bogunowicz, A. (1974). Nocardia pellegrini: III. Versuch einer Phagentypisierung. Zentralblatt fïr Bakteriologie, Parasitenkunde, Infektionskrankheiten und Hygiene (Abteilung I) 23I, 2 I4-222.

Prauser, H. (1970). Characters and genera arrangement in the Actinomycetales. In The Actinomycetales, pp. 407-418. Edited by H. Prauser. Jena: Gustav Fischer.

Ratledge, C. \& Patel, P. V. (I976a). The isolation, properties and taxonomic relevance of lipid-soluble, iron-binding compounds (the nocobactins) from Nocardia. Journal of General Microbiology 93, I4I-I 52.

RATledge, C. \& PATel, P. (1976 b). Lipid soluble, iron-binding compounds in Nocardia and related organisms. In The Biology of the Nocardiae, pp. 372-385. Edited by M. Goodfellow, G. H. Brownell and J. A. Serrano. London: Academic Press.

RAYMOND, R. L., JAMISON, V. W. \& HudSON, J. O. (1967). Microbial hydrocarbon co-oxidation. I. Oxidation of mono- and dicyclic hydrocarbons by soil isolates of the genus Nocardia. Applied Microbiology r5, $857-865$.

Refd, G. B. (1939). Proactinomyces Jensen. Bergey's Manual of Determinative Bacteriology, 5 th edn. Baltimore: Williams \& Wilkins.

RideLl, M. (1974). Serological study of nocardiae and mycobacteria by using 'Mycobacterium' pellegrino and Nocardia corallina precipitation reference systems. International Journal of Systematic Bacteriology 24, 64-72.

Ridell, M. \& Norlin, M. (1973). Serological study of Nocardia by using mycobacterial precipitation reference systems. Journal of Bacteriology $\mathbf{1} \mathbf{3}, \mathrm{I}-7$.

Rogosa, M., Cummins, C. S., Lelliott, R. A. \& Keddie, R. M. (I974). Bergey's Manual of Determinative Bacteriology, 8th edn. Edited by R. E. Buchanan and N. E. Gibbons. Baltimore: Williams \& Wilkins.

Rowbотнам, T. J. \& Cross, T. (1976). Rhodochrous-type organisms from freshwater habitats. Proceedings of the Society for General Microbiology 3, I00-IоI.

Rowвотнам, T. J. \& CRoss, T. (1977). Rhodococcus coprophilus sp. nov.: an aerobic nocardioform actinomycete belonging to the 'rhodochrous' complex. Journal of General Microbiology roo, I 23-138.

Runyon, E. H., Wayne, L. G. \& KubiCA, G. P. (1974). Bergey's Manual of Determinative Bacteriology, 8th edn. Edited by R. E. Buchanan and N. E. Gibbons. Baltimore: Williams \& Wilkins.

SNEATH, P. H. A. (1968). Vigour and pattern in 1axonomy. Journal of General Microbiology 54, I-I I.

SNeAth, P. H. A. (1972). Computer taxonomy. In Methods in Microbiology 7A, 29-98.

SNEATH, P. H. A. (1976). An evaluation of numerical taxonomic techniques in the taxonomy of Nocardia and allied taxa. In The Biology of the Nocardiae, pp. 74-Ior. Edited by M. Goodfellow, G. H. Brownell and J. A. Serrano. London: Academic Press.

SNeAth, P. H. A. \& Johnson, R. (1972). The influence on numerical taxonomic similarities of errors in microbiological tests. Journal of General Microbiology 72, 377-392.

Sneath, P. H. A. \& Sokal, R. R. (1974). Numerical Taxonomy. The Principles and Practice of Numerical Classification. San Francisco: W. H. Freeman. 
Sneath, P. H. A. \& Stevens, M. (1967). A divided petri dish for use with multipoint inoculators. Journal of Applied Bacteriology 30, 495-497.

SöHngen, N. L. (I913). Benzin, Petroleum, Paraffinöl und Paraffin als Kohlenstoff- und Energiequelle für Mikroben. Zentralblatt für Bakteriologie, Parasitenkunde, Infektionskrankheiten und Hygiene (Abteilung I) $37,595-609$.

SOKAL, R. R. \& Michener, C. D. (1958). A statistical method for evaluating systematic relationships. Kansas University Science Bulletin 38, 1409-1438.

Sokal, R. R. \& SNeath, P. H. A. (1963). Principles of Numerical Taxonomy. San Francisco: W. H. Freeman.

Staley, T. E. \& Colwell, R. R. (I973). Deoxyribonucleic acid reassociation among members of the genus Vibrio. International Journal of Systematic Bacteriology 23, 3I 6-332.

Tacquet, A., Plancot, M. T., Debruyne, J., Devulder, B., Joseph, M. \& Losfeld, J. (I97I). Études préliminaires sur la classification numérique des mycobactéries et des nocardias. I. Relations taxonomiques entre Mycobacterium rhodochrous, Mycobacterium pellegrino et les genres Mycobacterium et Nocardia. Annales de l'Institut Pasteur de Lille 22, I2I-135.

Trlford, P. E. (1936). Fasciation of sweet peas caused by Phytomonas fascians n. sp. Journal of Agricultural Research 53, 383-394.

Tsukamura, M. (I97I). Proposal of a new genus, Gordona, for slightly acid-fast organisms occurring in sputa of patients with pulmonary disease and in soil. Journal of General Microbiology 68, I 5-26.

Tsukamura, M. (1973). A taxonomic study of strains received as 'Mycobacterium' rhodochrous. Description of Gordona rhodochroa (Zopf; Overbeck; Gordon \& Mihm) Tsukamura comb. nov. Japanese Journal of Microbiology 17, I89-197.

Tsukamura, M. (1974). A further numerical taxonomic study of the rhodochrous group. Japanese Journal of Microbiology $\mathbf{1 8}, 37-44$.

TsukAmura, M. (1975). Numerical analysis of the relationship between Mycobacterium, rhodochrous group, and Nocardia by use of hypothetical median organisms. International Journal of Systematic Bacteriology 25, 329-335.

Tsukamura, M. \& Mizuno, S. (I971). A new species Gordona aurantiaca occurring in sputa of patients with pulmonary disease. Kekkaku 46, 93-98.

Tsuramura, M., Mizuno, S. \& Murata, H. (1975). Numerical taxonomy study of the taxonomic position of Nocardia rubra reclassified as Gordona lentifragmenta Tsukamura nom. nov. International Journal of Systematic Bacteriology 25, 377-382.

TURFITT, G. E. (I944). Microbiological agencies in the degradation of steroids. The cholesterol-decomposing organisms of soil. Journal of Bacteriology 47, 487-493.

Waksman, S. A. \& Henrici, A. T. (I948). Family Il. Actinomycetaceae Buchanan. In Bergey's Manual of Determinative Bacteriology, 6th edn. Edited by R. S. Breed, E. G. D. Murray and A. P. Hitchens. Baltimore: Williams \& Wilkins.

Willoughby, L. G. (I969). A. study of the aquatic actinomycetes of Blelham Tarn. Hydrobiologia 34, 465483.

ZopF, W. (1 89I). Über Ausscheidung von Fettfarbstoffen (Lipochromen) seitens gewisser Spaltpilze. Berichte der Deutschen botanischen Gesellschaft 9, 22-28. 